\title{
How Mongolian herders perceive ecological change in a "stable" landscape
}

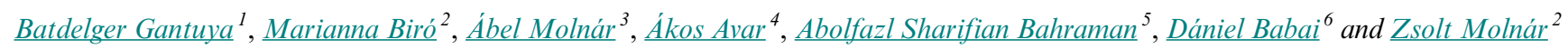

\begin{abstract}
Recently, climate change has had a considerable impact on rangelands, available forage, and shifting boundaries of ecological zones in Mongolia. Additionally, long-term studies in the forest-steppe zone show that increasing livestock pressure impacts vegetation composition and cover. Evidence shows that the traditional ecological knowledge of Mongolian herders can serve as a valuable body of information relevant to observations about these ongoing ecological processes. Among other things, a deeper understanding of how herders perceive ecological changes would be useful for improving pasture management and promoting natural regeneration processes. We conducted indoor and outdoor structured and semi-structured interviews, with additional landscape walks and participatory fieldwork. In total we interviewed 33 people, all full-time herders. We found 32 indicators on how herders perceived landscape and vegetation changes for the 14 habitat types studied. Herders had deep knowledge of their landscape, and they attributed various changes to diverse drivers on their grasslands, wetlands, and forests. Among herders there was variation in the perceived importance of droughts and increasing livestock numbers. The perceived changes and indicators could be grouped into three main categories, namely long-term (decadal) trends, regenerative successions after disturbance, and recurrent fluctuations caused mainly by weather. Some of the long-term trends reported by herders are well-known, e.g., worsening of rangeland production, others, like the blackening of tussocks, or the impact of oilskin on yurt site regeneration, are rarely mentioned in the scientific literature, if at all. South-facing mountain slopes and flat areas in valleys were reported as the locations where vegetation change takes place most rapidly. To reverse adverse changes, herders wish to cooperate especially with each other to increase mobility, stop overgrazing, and help nature to regenerate their worsening pastures. We conclude that herders have a reliable and widely shared understanding of landscape and pasture changes that could help with this cooperation.
\end{abstract}

Key Words: forest-steppe; indicators; landscape changes; perception; regeneration; succession; traditional ecological knowledge; trends

\section{INTRODUCTION}

Landscapes are complex social-ecological systems (Bieling 2013), in which natural and anthropological drivers generate a variety of changes (Bürgi et al. 2005). These changes may have fundamental impacts on local livelihoods, especially in communities dependent on local natural resources, such as nomadic livestock keepers utilizing unfenced rangelands (Johnson et al. 2006). In Mongolia, livelihoods and livestock production systems have changed drastically since 1990 because of the transformation from a communist to a free-market economy (Fernández-Giménez 1999a, b, Johnson et al. 2006, Okayasu et al. 2007, Galvin 2009, Lkhagvadorj et al. 2013a).

Herders in Mongolia have always lived in extreme environments with many challenges in adapting to the unpredictable availability of forage resources (Galvin 2009, Fernández-Giménez et al. 2015a, Du et al. 2018). Recently, climate change has had a considerable impact on rangeland condition, available forage production, water resources, and shifting boundaries of ecological zones (Angerer et al. 2008, Venable et al. 2012, Fernández-Giménez et al. 2017). Long-term vegetation ecological and remote sensing studies show that the increasing impact of livestock grazing on pastures not only reduces the cover of the dominant, good-quality forage plants, but also drastically changes the functioning of the whole ecosystem in large areas in Mongolia (Gunin et al. 1999, Chognii 2001, Tuvshintogtokh and Ariungerel 2013, Lamchin et al. 2016). Increasing livestock numbers and worsening weather conditions had adverse effects on total vegetation cover, biomass, and the species diversity of meadow steppes of the forest-steppe zone as well (Otgontuya et al. 2019). Because intensification, e.g., fertilization and sowing perennial grass varieties, is not a widely applicable solution in Mongolia on account of the harsh climatic conditions (short growing season), it is increasingly necessary to rely on natural spontaneous regeneration, especially in areas with water scarcity, poor soils, and rocky terrains (Chognii 2001). Khishigbayar et al. (2015) and Bestelmeyer et al. (2017) argue that most of the degraded pastures in Mongolia could still recover with appropriate utilization, e.g., with higher mobility of herds and more widespread pasture resting, but if current grazing practices and grazing pressures continue, there is a low chance of recovery.

Chognii (2001) emphasizes that a better understanding is needed of degradative changes and natural regeneration processes of Mongolian pastures. Among other things, a better understanding of how local herders perceive landscape and pasture changes would be beneficial (cf. Gantuya et al. 2019, Jamsranjav et al. 2019, Molnár et al. 2020).

Traditional ecological knowledge and local perceptions based on this knowledge could serve as a valuable source of information about the natural environment and the ongoing ecological processes in Mongolia (Fernández-Giménez 1993, 2000, Kristjanson et al. 2009, Gantuya et al. 2019, Jamsranjav et al. 2019). Traditional ecological knowledge is related to the cornerstone elements (flora, fauna, habitats, soils, etc.) of a

${ }^{1}$ Botanic Garden and Research Institute, Mongolian Academy of Science, Ulaanbaatar, Mongolia, ${ }^{2}$ Centre for Ecological Research, Institute of Ecology and Botany, Vácrátót, Hungary, ${ }^{3}$ Hungarian University of Agriculture and Life Sciences, Doctoral School of Biological Sciences, Gödöllö, Hungary, ${ }^{4}$ Department of Mongolian and Inner Asian Studies, Eötvös Loránd University, Budapest, Hungary, ${ }^{5}$ Department of Rangeland and Watershed Management, Gorgan University of Agricultural Sciences and Natural Resources, Gorgan, Iran, ${ }^{6}$ Institute of Ethnology, Research Centre for the Humanities, Budapest, Hungary 
landscape. Changes are connected to these cornerstones, and members of the local communities perceive these changes (Ujházy et al. 2020).

Under traditional ecological knowledge we understand the cumulative body of knowledge, practice, and belief, evolving by adaptive processes and handed down through generations by cultural transmission in traditional communities, about the relationship of living beings (including humans) with one another and with their environment (Berkes 2017). Meanwhile, we refer to perception as the way an individual observes, understands, interprets, and evaluates a landscape element, its change, and the drivers affecting this change. Observations are based on sensory experiences, while interpretations are socially constructed and mirror the relationships, including relational values of the observer to the perceived object (Bennett 2016). Local perception helps produce knowledge about the environment, through living in close relationship with the surrounding environment (Ingold 2000).

Mongolian herders' ecological knowledge refers, among others, to different wild plant and animal species, their uses, and their relative nutritional and other values (Fernández-Giménez 2000, Samiya and Mühlenberg 2006). Mongolian herders can reliably estimate pasture conditions and the impact of climate change or other direct (ecological and anthropological) and indirect (e.g., socioeconomic or political) drivers (Fernández-Giménez 1993, 2000, Marin 2010, Kakinuma and Takatsuki 2012, FernándezGiménez et al. 2015b, Gantuya et al. 2019).

Changes in a landscape are diverse, from long-term (decadal or longer) more or less unidirectional trends (worsening rangeland production, increasing or decreasing forest area), through regenerative successions after a disturbance (like development of forest after fire or grassland on abandoned livestock resting places), to recurrent fluctuations (fluctuation of some populations caused mostly by fluctuating weather, droughts or floods; Solomon and Shugart 1993). Traditional management systems are usually based on traditional ecological knowledge embedded in local worldviews. Neither knowledge nor main practices are static (Berkes et al. 2000). Adaptations of management practices are based on perceptions of changes and monitoring of impacts, and are affected by the values held by the members of the local community (Berkes et al. 2000, Chan et al. 2016, Kis et al. 2017). Globally, there is a growing body of evidence that traditional ecological knowledge of herders and scientific knowledge, as equally contributing partners, can generate a more complete and relevant understanding of the dynamics of landscapes, ecosystems, and management systems (Huntington 2000, Moller et al. 2004, Tengö et al. 2014, Molnár et al. 2016a). Understanding traditional ecological knowledge and local perceptions can help develop culturally and ecologically more adequate and relevant bottom-up or top-down natural resource management systems and policies to ensure long-term sustainability in these landscapes (Reed et al. 2006, Babai et al. 2015).

In this paper, our objectives were to assess how herders perceive fine-scale (often habitat specific) landscape changes, including long-term trends, the types of regenerative successions, and recurrent fluctuations of the 14 main local habitat types (grasslands, wetlands, forests, shrub vegetation, etc.). In parallel, we also documented some Mongolian worldview elements (values, interpretations, beliefs) held by herders that underpin these perceptions, and also some suggestions by local herders to reverse recent observed adverse changes. We worked in two Mongolian mountain forest-steppe areas that have similar topography, vegetation, and land use. Additionally, we discuss how the local herders' understanding of landscape dynamics could be of benefit to the long-term sustainable utilization of pasture resources.

\section{STUDY AREA AND METHODS}

\section{Study area}

Our study areas were Khangai soum (soum: sub-province in Mongolia) in Arkhangai province (coordinates: N 47 51'12", E 99 $25^{\prime} 42^{\prime \prime}, 2500-3456 \mathrm{~m}$ a.s.1.), and Arbulag soum in Khuvsugul province (coordinates: N 50²2'47", E 99³1'52", 1300-1900 m a. s.1.), which are both located in the mountain forest-steppe of the Khangai region (Fig. 1) and lie in the permafrost region (Kynický et al. 2009), characterized by high mountains, steep and gentle slopes and hills, rocky outcrops, and river floodplains. The climate is cold, the vegetation period is short, the mean temperature is -34 to $-30{ }^{\circ} \mathrm{C}$ in January, +15 to $+20^{\circ} \mathrm{C}$ in July, and mean annual precipitation is approximately $200-400 \mathrm{~mm}$. According to the data of the National Agency of Meteorology and Environmental Monitoring (NAMEM), between 1980 and 2019, there was no sharp increase, only a slight increase or decrease in the average temperature and precipitation in both provinces. However, there was noticeable change between 2000 and 2010, when temperature increased and precipitation decreased (NAMEM 2019; P. Batima, L. Natsagdorj, P. Gombluudev, et al., 2005, unpublished manuscript).

Fig. 1. Geographical location of the study areas in Mongolia; Arbulag and Khangai soums marked with asterisk (source of map elements: ArcGIS 10.1, ESRI; Natural Earth).

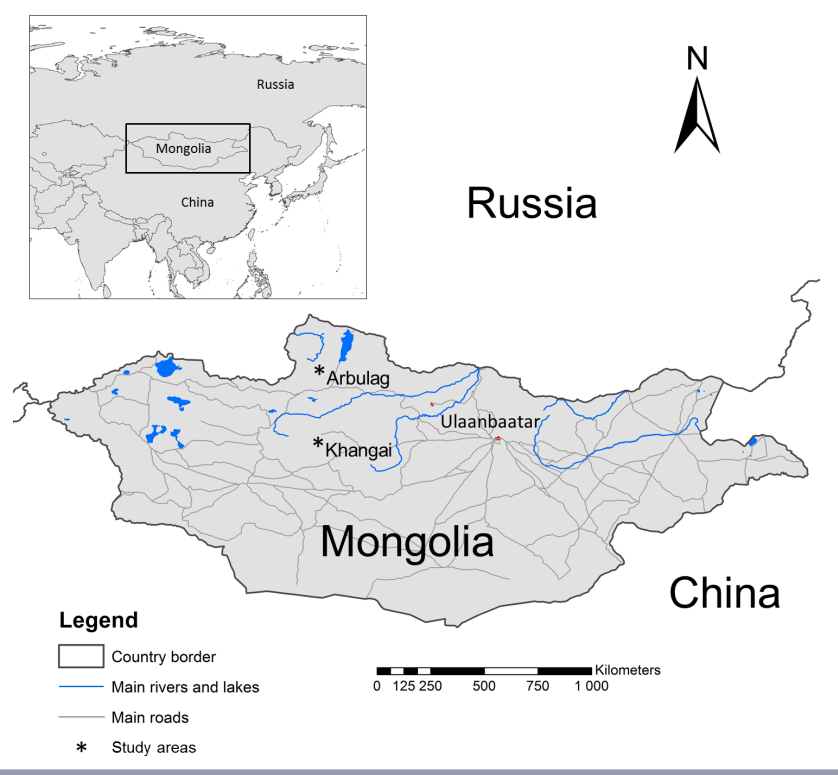


Table 1. Main habitat types, their local folk names (based on Gantuya et al. 2019), and the characteristic plant species of the study areas in Khangai and Arbulag soums. Habitats and lists of species cover both soums. A: the species occurs only in Arbulag.

\begin{tabular}{|c|c|}
\hline Main habitat types and their folk names & Characteristic vascular plant species \\
\hline $\begin{array}{l}\text { Alpine zone (above the tree line): Tag, } \\
\text { tsaram, modnii tsaram }\end{array}$ & $\begin{array}{l}\text { Lagotis integrifolia (Willd.) Schischk., Dryas oxyodonta Juz., Claytonia joanneana Roem. et Schult., Salix } \\
\text { berberifolia Pall., Saussurea involucrata (Kar. et Kir.) Sch. Bip., Erigeron flaccidus (Bunge) Botsch., } \\
\text { Dracocephalum grandiflorum L. }\end{array}$ \\
\hline $\begin{array}{l}\text { A: Taiga forests (closed, mossy): Taiga, } \\
\text { taigarkhag gazar }\end{array}$ & $\begin{array}{l}\text { Vaccinium vitis-idaea L., Ledum palustre L., Rhododendron parvifolium Adams, Empetrum sibiricum V. } \\
\text { Vassil., Thalictrum alpinum L., Pyrola incarnata (DC.) Freyn, Linnaea borealis L., Juniperus sibirica Burgsd. }\end{array}$ \\
\hline Larch forests: $O i$, oi dotor & $\begin{array}{l}\text { Thalictrum petaloideum L., Calamagrostis purpurea (Trin.) Trin., Artemisia laciniata Willd., Dianthus } \\
\text { superbus L., Pedicularis verticilliata L., Vicia amoena Fisch., Aconitum barbatum Pers., Valeriana officinalis } \\
\text { L. }\end{array}$ \\
\hline Forest fringes: Oin zakh, modnii zakh & $\begin{array}{l}\text { Pulsatilla turczaninovii Kryl. et Serg., P. flavescens (Zucc.) Juz., Potentilla fruticosa L., Anemone crinita Juz., } \\
\text { Trollius asiaticus L., Gentiana macrophylla Pall., Salix pseudopentandra (B.Flod.) B.Flod., Salix kochiana } \\
\text { Trautv. }\end{array}$ \\
\hline $\begin{array}{l}\text { Screes, rocks in the forest: Asga, khad asgan } \\
\text { dund }\end{array}$ & $\begin{array}{l}\text { Caragana jubata (Pall.) Poir., Ribes altissimum Turcz. ex Pojark., Rosa acicularis Lindl., Berberis sibirica } \\
\text { Pall., Grossularia acicularis (Smith) Spach., Lonicera altaica Pall. ex DC., Atragene sibirica L. }\end{array}$ \\
\hline South-facing slope: Uuliin enger, övör & $\begin{array}{l}\text { Allium altaicum Pall., Androsace incana Lam., Schizonepeta multifida (L.) Briq., Festuca lenensis Drob., } \\
\text { Koeleria cristata (L.) Pers., Thymus gobicus Tschern., Echinops latifolius Tausch., Chamaerhodos altaica } \\
\text { Bge., Orostachys spinosa (L.) C.A.Mey., }\end{array}$ \\
\hline North-facing slope: Uuliin ar & $\begin{array}{l}\text { Erigeron flaccidus (Bunge) Botsch., Potentilla fruticosa L., Pulsatilla flavescens (Zucc.) Juz., Kobresia sibirica } \\
\text { (Turcz. ex Ledeb) Boeck., Potentilla nivea L., Hierochloa alpina (Sw.) Roem. et Schult, Calamagrostis } \\
\text { purpurea (Trin.) Trin. }\end{array}$ \\
\hline $\begin{array}{l}\text { Meadows close to the stream and river: } \\
\text { Shireg gazar, sudag gazar }\end{array}$ & $\begin{array}{l}\text { Carex duriuscula L., Pedicularis longiflora Rudolph., Primula nutans Georgi., Carex pediformis C.A.Mey., } \\
\text { Juncus leucochlamys Zing. ex V.Krecz. Gentiana algida Pall., Halenia corniculata (L.) Cornaz., Lagotis } \\
\text { integrifolia (Willd.) Schischk }\end{array}$ \\
\hline Tussocky area: dovorkhog gazar, dovon dund & $\begin{array}{l}\text { Bistorta vivipara (L.) S.F.Gray, Lomatogonium carinthiacum (Wulf.) Reichenb., Cirsium esculentum C.A. } \\
\text { Mey., Parnassia palustris L., Potentilla anserina L., Rumex acetosa L. }\end{array}$ \\
\hline $\begin{array}{l}\text { Meadow steppes close to the forest and in } \\
\text { valley bottoms: uuliin bel, including } \\
\text { hayfields, nuga }\end{array}$ & $\begin{array}{l}\text { Aconogonon angustifolium (Pall.) Hara, Hordeum brevisubulatum (Trin.) Link., Koeleria cristata (L.) Pers., } \\
\text { Poa subfastigiata Trin., Carex pediformis C.A.Mey., Galium verum L., Eriophorum polystachyon L., Salix } \\
\text { glauca (Bunge) Bunge, Potentilla fruticosa L., Sanguisorba officinalis L. }\end{array}$ \\
\hline $\begin{array}{l}\text { Flat area (in wide valley): Tal gazar, nam dor } \\
\text { gazar }\end{array}$ & $\begin{array}{l}\text { Artemisia frigida Willd., Leontopodium ochroleucum Beauvd., Taraxacum officinale Wigg., Carex duriuscula } \\
\text { C. A. Mey., Gentiana decumbens L.f., Astragalus galactites Pall., Smelowskia alba (Pall.) Regel., Potentilla } \\
\text { anserina L. }\end{array}$ \\
\hline Sayrs (gravel bars): Goliin sair, sairan deer & $\begin{array}{l}\text { Dianthus versicolor Fisch., Orostachys spinosa (L.) C.A.Mey., Dracocephalum foetidum Bge., Lagopsis } \\
\text { marrubiastrum (Steph) Ik.-Gal., Papaver nudicaule L., Chamaerhodos erecta (L.) Bge. }\end{array}$ \\
\hline $\begin{array}{l}\text { Near marmot burrows: tarvaganii dosh, } \\
\text { nükhnii oiroltsoo }\end{array}$ & $\begin{array}{l}\text { Rheum undulatum L., Artemisia dracunculus L., Agropyron cristatum (L.) Beauv., Dracocephalus foetidum } \\
\text { Bunge., Chenopodium album L., Rhodiola rosea L. }\end{array}$ \\
\hline $\begin{array}{l}\text { Disturbed and ruderal places: Khöl (buudal) } \\
\text { gazar, khashaa buutsnii zakh, including } \\
\text { hayfields }\end{array}$ & $\begin{array}{l}\text { Draba nemorosa L., Lappula intermedia (Ldb.) Pop., Lepidium ruderale L., Plantago major L., Polygonum } \\
\text { aviculare L., Leptopyrum fumarioides Reichb., Potentilla anserina } \text { L., Urtica cannabina L., Chenopodium } \\
\text { album L., Artemisia macrocephala Jacq. ex Bess., Agropyron cristatum }(\text { L.) Beauv. }\end{array}$ \\
\hline
\end{tabular}

The main source of income is livestock husbandry, including sheep, goats, yaks, cattle, and horses. Livestock numbers have increased in both soums (Khangai: 1980: 82,000; 2019: 135,000; Arbulag: 1980: 130,000; 2019: 418,000 head of livestock) with decreases usually only occurring in years with extremely severe weather (called $d z u d$; NSO 2019).

In Khangai soum, land-use rights are mostly managed through customary cooperative systems called khot ail, formed by two or more households mainly based on kin relations. Members of khot ail pool their herds to share labor, manage herding on common natural lands through task sharing, and make hay together. In Arbulag soum, herder households camp individually and herd separately, although spatially close to each other.

The vegetation of the two study areas is similar (Table 1, Fig. 2). It is dominated by larch (Larix sibirica Ledeb.) forests on northern slopes and grasslands on south-facing slopes and in the valleys. Forests in Arbulag have more taiga species, and bushes are mostly typical along forest fringes. Grasslands are species-rich mountain meadow-steppes with short grass height $(<10-20 \mathrm{~cm})$, which are moderately or heavily grazed. The typically closed grass sward only opens up on dry, sunny, and rocky slopes. Wetlands occur along water courses and around springs. Sayrs (gravel bars) have denser vegetation in Khangai and are more often grazed than in Arbulag.

\section{Data collection and analysis}

We collected data between 08-25 June 2017, 05-23 July 2018, and 28 July-06 August 2019 in Arbulag soum, and 16-27 July 2019 and 12-23 August 2019 in Khangai soum. Indoor and outdoor structured and semi-structured interviews were conducted, with additional landscape walks and participatory fieldwork. This combination of methods was successfully used to reconstruct herders' and farmers' knowledge and perceptions in Hungary, Romania, and Mongolia (Babai and Molnár 2014, Molnár 2014, Gantuya et al. 2019). Interviews lasted from 20 to 120 minutes. All interviews were digitally recorded using a voice recorder. Prior informed consent was sought, following the guidelines of the International Society of Ethnobiology (ISE 2006) and the general data protection regulation of the European Union. 
Fig. 2. Vegetation map of the studied areas (left: Arbulag soum, Khuvsugul province, source: Gantuya et al. 2019; right: Khangai soum, Arkhangai province, Mongolia; source of satellite images: Bing Maps).

\section{Legend}
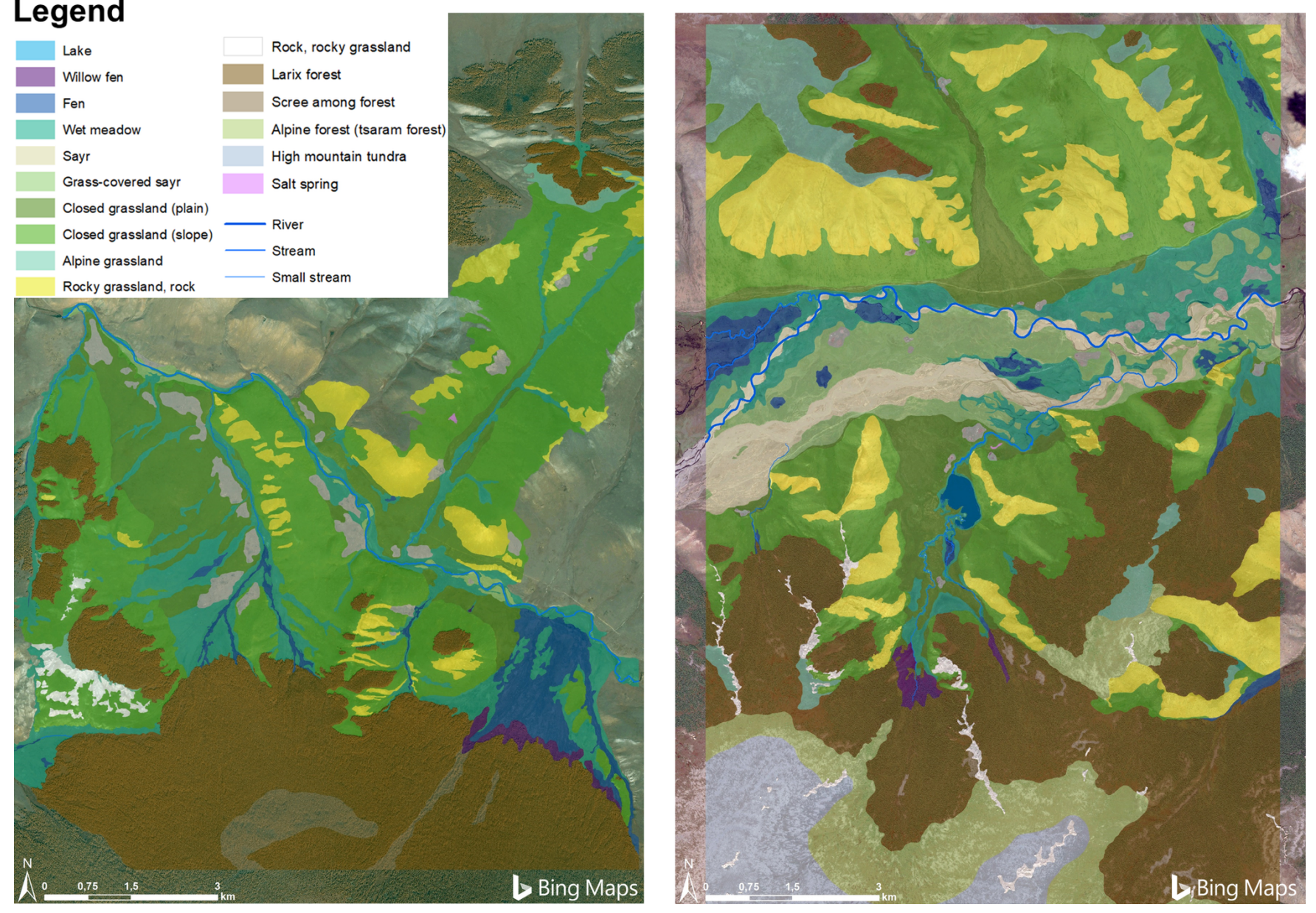

Based on a literature review, we listed in advance the most important indicators pastoral communities use (e.g., from Angassa and Beyene 2003, Jandreau and Berkes 2016; and in Mongolia, Bruegger et al. 2014, Kakinuma et al. 2014, Jamsranjav et al. 2019). We then searched for these and further spontaneously arising indicators during our interviews and landscape walks. We focused on the main folk habitat types documented by Gantuya et al. (2019), but remained open to discussion of additionally mentioned habitat types. The main questions were (based mostly on Molnár 2014, 2017, Ujházy et al. 2020) the following: What changes do you remember since your childhood in areas like this in the picture/in this area on the opposite mountain side, etc.? What are the most important characteristics of this particular area? Which species have increased / decreased / appeared / disappeared since your childhood? What were the causes of "a certain change" (e.g., worsening pasture conditions, appearance or disappearance of a given species mentioned by the participants)? How was that area used in the past? How many head of livestock graze / used to graze this area?

During interviews, to confirm which habitat types the interview was about, we used 14 printed color photos of habitats of the local landscape. Additionally, we asked herders to group together habitats (using the photos provided) that have changed the most or the least since their childhood (pile sorting exercise; Rugg and McGeorge 1997, Molnár 2012). During the first interviews we realized that additional specific questions were needed in order to gain a better understanding of elements of the local worldview that may impact perceptions of landscape change. To achieve this, we completed a series of interviews with seven additional respondents asking what nature gives to Mongolian herders, what nature teaches herders, how herders cooperate with nature, how herders help nature to cope with landscape changes, and what solutions they would suggest to deal with adverse changes. Data on landscape changes mentioned by the interviewees mostly referred to the last $30-50$ years.

In total we conducted 26 structured and 28 semi-structured interviews with 33 herders ( 12 males in each soum, 2 females in Khangai, 7 females in Arbulag). Structured interviews helped us to ask about changes for all the habitat types and key landscape changes, while semi-structured interviews gave us an opportunity to spontaneously explore related relevant topics during the 
interviews and landscape walks. Interviewees were aged between 30 and 71 years, and the average age was 46 . All were full-time herders having on average 200-500 sheep and goats, 30-90 cattle, 50-200 yaks, and 10-25 horses per family. They change camp sites four or five times a year; camp sites are located 3-120 km from each other. Men spend more time with the herds out in the landscape, so we focused on men, although we also interviewed women to decrease gender bias. Women were especially knowledgeable on medicinal plants and key forage species. We chose typical forest-steppe areas for our research (see the landscape structures and vegetation patterns in Fig. 2), and selected interviewees from different parts of these landscapes. During landscape walks we visited different parts of these landscapes.

The voice recordings and notes were transcribed, and the data were coded according to the subject (indicator, habitat, type of change). The information collected during the interviews and participant observations was analyzed and presented qualitatively. The frequency of mentions of indicators was analyzed semi-quantitatively because some landscape changes were verbalized using combined indicators: "few" mentions (less than five herders mentioned the indicator explicitly); "several" mentions (5-12 herders mentioned); mentioned by "many" herders (13-20); and mentioned by (almost) "all” herders (21-26). Below, we quote whole sentences, sometimes half sentences, or only specific key expressions, and present some of the most typical and particularly interesting responses in the form of translations of verbatim quotes (quotes by different herders are separated by a slash [/]).

We conducted vegetation and flora surveys to obtain a basic botanical understanding of the landscape prior and parallel to the interviews. These data were not used directly but informed the authors about the key ecological features of the local landscape. Based on the data of the botanical surveys, we delineated habitat patches on printed satellite images (Bing Maps satellite images [Microsoft] in QGIS Desktop 3.4.3. software) using the main folk habitat types documented in Gantuya et al. (2019). We prepared the map of geographical location and the habitat maps using ArcGIS 10.1 (ESRI 2012) and QGIS Desktop 3.4.3. (QGIS Development Team) software, Bing Maps, and Natural Earth (https://www.naturalearthdata.com/downloads/) data (Figs. 1 and 2). Maps indicate that the two landscapes are very similar regarding the list and pattern of habitats, and the proportion and patchiness of forests, grasslands, and wetlands.

\section{RESULTS}

Herders mentioned a total of 32 indicators of landscape and vegetation change. Indicators were sorted into three main groups: trends, regenerative successions, and fluctuations (see Table 2 for a summary).

\section{Trends}

Mongolian herders observed and reported a considerable diversity of trends happening in their landscape using 24 indicators.

\section{Change in rangeland production}

All herders in both areas reported that rangeland production has deteriorated. Two reasons were mentioned: the drought years in
2000 and between 2001 and 2008, and the increase in livestock numbers. "In the past, the summer place had endless grass, no matter how it was used."

All herders mentioned, however, that rangeland production has improved slightly in the last two to three years, as precipitation has increased and some herders rested their pastures. "Plant density became relatively good, after we rested our pastures from June until August." A few herders added, "although this year is good, some mountain slopes could not recover as well as in the past, because the grass roots withered completely in the drought years."

A few herders mentioned that "in the past, when the state meat was prepared on 15 May, all the livestock were full of grass. Now, on 20 June, almost July, the livestock is still not satisfied and the sheep are not yet shedding their wool."

\section{Decrease in hay quantity and quality}

Most herders did not report any change in the quality of hay grass per se. Several herders mentioned that the amount of grass has declined, the grass height is shorter owing to the increase in livestock numbers and the changing climate. "In the past, more than 60-90 haystacks were made from the fenced hayfield of the wintering place, now we get only 10-20 (30) haystacks." A few herders said that the quality of the hay is also worsening through disturbance by grazing.

\section{Change in haymaking time}

Many herders mentioned that the haymaking time has not changed and they usually do haymaking between 10 and 20 August. Nevertheless, several herders said that the haymaking time has shifted slightly earlier. "Now we cannot make hay in September because the weather is getting cold, and the grass is drying up [turning yellow] early."

\section{Decrease in vegetation cover}

All herders in both study areas said that vegetation has become sparser. The changes started around 1990, and they also blamed the changes on some extreme drought years, especially 2000, 2002, and 2015. Most herders mentioned that drought and the increase in livestock numbers have exerted the highest impact on vegetation cover, although a few herders mentioned only climate conditions as having a significant impact: "If the pastures were sparse because of the influence of livestock, this pasture would be completely over by today, there was a lot of livestock grazing here [even] in the past." However, one herder argued "that all factors are important to some extent. Denying the impact of increased livestock numbers on pasture degradation is a one-sided concept."

\section{Change in plant height}

All herders stated that plants have become smaller, especially in flat areas and valleys. Even weeds that grow near the livestock corrals such as luuli (Chenopodium album L.) and sharilj (Artemisia sp.) have dwarfed. Most herders added that the grass on north-facing mountain slopes still grows to a similar height today as it did previously. In general, "during the last two years [with more rain] grasslands started to regenerate, but the grass is not as tall as it was 30-40 years ago. In the past flat areas in valleys were as tall as forest edges today." 
Table 2. Indicators of landscape and vegetation changes (trends, regenerative successions, and fluctuations) with frequency of mentions by herders $(* * * *$ : mentioned by [almost] all herders, ***: by many herders, **: by several herders, *: by a few herders only), habitats where these changes were observed and reported, and drivers as understood and reported by Mongolian herders. Drivers: LI: livestock numbers increasing, DP: decrease in precipitation and droughts, CC: climate change in general, HU: human utilization, GHDR: goats and horses dig roots.

\begin{tabular}{|c|c|c|c|}
\hline Indicators of landscape change & $\begin{array}{c}\text { Frequency of } \\
\text { mentions }\end{array}$ & Habitats & Drivers \\
\hline \multicolumn{4}{|l|}{ Trends } \\
\hline 1. Change in rangeland production & $* * * *$ & Almost all pastures & LI, DP \\
\hline 2. Decrease in hay quantity and quality & $* *$ & Hayfields & LI, DP \\
\hline 3. Change in haymaking time & $* * *$ & Hayfields & $\mathrm{CC}$ \\
\hline 4. Decrease in vegetation cover & $* * * *$ & Almost all pastures & LI, DP \\
\hline 5. Change in plant height & $* * * *$ & Almost all pastures & LI, DP \\
\hline $\begin{array}{l}\text { 6. Change in plant population sizes of useful } \\
\text { plants }\end{array}$ & $* * * *$ & General & LI, DP, HU \\
\hline 7. Increase in weed and pest populations & $* *$ & $\begin{array}{l}\text { Disturbed place by Brandt's vole } \\
\text { (Lasiopodomys brandtii), along the road, } \\
\text { near the dung }\end{array}$ & LI, DP, Brandt's vole \\
\hline 8. Increase in unknown, unfamiliar plants & $* * *$ & $\begin{array}{l}\text { Disturbed place by Brandt's vole, along } \\
\text { the road, near the dung }\end{array}$ & DP, Brandt's vole \\
\hline 9. Shrinking of plant roots & $* * *$ & South-facing slopes & $\begin{array}{l}\text { LI, DP, GHDP, heavy rain (hail), spring } \\
\text { flooding }\end{array}$ \\
\hline 10. Decrease of plant quality (species traits) & ** & Slope and foothill habitats & $\mathrm{DP}$, rangeland production is worsening \\
\hline 11. Change in shrub vegetation & $* * *$ & $\begin{array}{l}\text { Near or along forest edges, valleys, and } \\
\text { flat areas }\end{array}$ & Livestock seldom graze because of mosquitoes \\
\hline 12. Change in forest vegetation & $* * *$ & $\begin{array}{l}\text { Larch forests, including taiga forests } \\
\text { (closed, mossy), small forest }\end{array}$ & $\begin{array}{l}\text { DP, Trees are long-lived plants, forests change } \\
\text { slowly, HU, people cut only dead trees, insect } \\
\text { outbreaks, wild animals }\end{array}$ \\
\hline 13. Change in the sayr and its vegetation & $* * * *$ & Sayrs & Decreasing water levels and river floods, GHDP \\
\hline $\begin{array}{l}\text { 14. Changes in bare ground and rocks, } \\
\text { erosion }\end{array}$ & $* * *$ & South-facing slopes & DP \\
\hline $\begin{array}{l}\text { 15. Changes in the regeneration of } \\
\text { abandoned yurt sites }\end{array}$ & $* * * *$ & Abandoned yurt sites & Oilskin is used \\
\hline 16. Change in vegetation type & $*$ & $\begin{array}{l}\text { In the shireg and sudag (greener } \\
\text { meadows and south-facing slopes) }\end{array}$ & DP \\
\hline 17. Decrease in permafrost & $*$ & Not relevant & $\mathrm{CC}$ \\
\hline $\begin{array}{l}\text { 18. Reduction of water in the landscape in } \\
\text { general }\end{array}$ & $* * *$ & General & DP, cutting of trees \\
\hline 19. Changes in tussocks & $* * * *$ & Tussocky place along the river & LI, DP, lack of moisture \\
\hline 20. Changes in rocks & $* * * *$ & Rocks & Influence of wind, water, and lightning \\
\hline 21 Changes in soil & $* * *$ & General & LI, natural change \\
\hline 22. Changes in wildlife populations & $* * *$ & General & $\begin{array}{l}\text { Hunting and ban on hunting, penalty, market } \\
\text { prices, and DP }\end{array}$ \\
\hline $\begin{array}{l}\text { 23. Changes in the physical parameters of } \\
\text { wild animals (traits) }\end{array}$ & $* * *$ & General & Reduction in forage plants \\
\hline $\begin{array}{l}\text { 24. Changes in the physical parameters of } \\
\text { livestock }\end{array}$ & $* * *$ & General & Reduction in forage plants \\
\hline \multicolumn{4}{|l|}{ Regenerative successions (with no decadal trends) } \\
\hline $\begin{array}{l}\text { 25. Regeneration of abandoned livestock } \\
\text { corral sites }\end{array}$ & $* * * *$ & $\begin{array}{l}\text { Disturbed place, along the road, near } \\
\text { the dung }\end{array}$ & Abandonment from use \\
\hline 26. Regeneration of other weedy areas & $* * *$ & $\begin{array}{l}\text { Disturbed place, along the road, near } \\
\text { the dung }\end{array}$ & Abandonment from use \\
\hline $\begin{array}{l}\text { 27. Regeneration of abandoned yurt sites } \\
\text { (with felt carpets) }\end{array}$ & $* * * *$ & Yurt sites & Abandonment from use \\
\hline 28. Succession after forest fire & $* * *$ & Forest & Fire \\
\hline \multicolumn{4}{|c|}{ Fluctuations of plant populations and other repetitive changes } \\
\hline 29. Fluctuation of some plant populations & $* * *$ & General & DP \\
\hline 30. Fluctuation of some animal populations & ** & General & DP \\
\hline $\begin{array}{l}\text { 31. Change of the shores of large rivers and } \\
\text { sayr }\end{array}$ & $* * * *$ & Riverbank & Flood \\
\hline 32. Damage to trees and branches & $*$ & Forest & Wet snow in autumn \\
\hline
\end{tabular}


Table 3. Long-term changes (or no change) of plant populations and the attributed drivers reported by local herders in the studied forest-steppe areas in Khangai and Arbulag soums, Mongolia.

Increased plant species

Allium altaicum Pall.

Species that have not changed

Lonicera altaica Pall. ex DC., Gentiana algida Pall., Ribes altissimum

Turcz. ex Pojark. Saussurea involucrata (Kar. et Kir.) Sch.Bip.

Salix sp. and Caragana sp.

Mosses

Decreased plant species:

Festuca lenensis Drob. on mountain slopes, Carex sp. and Polygonum viviparum L. on tussocks, Potentilla fruticosa L., Potentilla anserina L., and Taraxacum sp. shar mulch and chikhen nogoon

Festuca rubra L., Vicia cracca L. and Hordeum brevisubulatum (Trin.) Link. in the forest, khazaar nogoo Festuca rubra, Gentiana algida Pall., Dianthus superbus L. in forest fringes, and Dianthus versicolor Fisch. ex Link. Polygonum spp. (honin, aduun and ukher badgana) on the sayr Rhodiola rosea L., Geranium pratense L. and Allium altaicum Pall.

Salix sp. near the river

Locally disappeared plant species:

Salix sp. /shrub patches

\begin{abstract}
Attributed drivers reported by herders:
We have some places where people never pick an onion, onion has a lot of seeds, people pick it only in the autumn after the onion turns yellow
\end{abstract}

Livestock do not eat them, and there is no change even if locals collect fruits

Usually grazed in autumn and winter (no harm to the plant)

People do not use mosses, and livestock do not eat them

High livestock numbers / Dryness and lack of water

Dryness

Dryness / Human collection in some places

Roots rot because of floods

Washed away by floods, frozen in winter, browsed by livestock in summer, dryness, drought years, pulled out and eaten by horses in winter

\section{Change in plant population sizes of useful plants}

All herders reported that the number of rangeland plant species on pastures has fallen because of increasing livestock numbers and drought years. Many herders observed that nariin ovs (grass, mostly including the genera Festuca and Koeleria, which grow in dry areas) such as botuul (Festuca lenensis Drob.) has declined. "Some plants that used to grow [here] when I was young have significantly decreased. / Rangeland plants such as botuul, altan gagnuur (Rhodiola rosea L.), songino (Allium altaicum Pall.) and bugiin zogdor (Carex pediformis C.A.Mey.) are declining." Several herders mentioned the same trend for khuren tolgoit [brownheaded] borog (Carex sp.), ulaan borog (Carex sp.) in shireg place (near the streams), and for ulaan botuul (Festuca rubra L.), darsh (Vicia sp.), and hyag (Agropyron cristatum (L.) Beauv.) in the forest. Some herders could not recall exactly which species are in decline.

Many herders said that some important species have reduced in number because of human collection for consumption (Allium altaicum, Rhodiola rosea) and markets (Allium altaicum) in both soums. "I used to pick $50 \mathrm{~kg}$ sacks full of onions. It took two hours in the past, and now I can dig $50 \mathrm{~kg}$ maybe [only] in a whole day. I Altan gagnuur (Rhodiola rosea) is becoming a rare plant here, some people steal it at night."

By contrast, several herders mentioned that wild onion is on the increase in some areas of Khangai soum, although they use it every year. "Onions are growing very well, and black seeds are sprouting. / The reason for no reduction is that the onion itself has a lot of seeds." In Khangai soum, several herders reported no decrease in some plant species that are used by locals, such as Allium altaicum, Gentiana algida Pall., Lonicera altaica Pall. ex DC., Ribes altissimum Turcz. ex Pojark. as well as mosses (Table 3).

\section{Increase in weed and pest populations}

Several herders in both soums observed that weeds have been proliferating because of increased dust, manure, and desertification. "A lot of sharilj are growing along roads because they get dusty. Üliin tsagaan ogotno (Brandt's vole, Lasiopodomys brandtii) has increased in the last decades because of dry weather, and it is the real enemy of pasture, and I heard that the Brandt's vole is a very fast-breeding animal, it breeds 3-4 times a year."

\section{Increase in unknown, unfamiliar plants}

Many herders mentioned that unfamiliar plants ("various strange flowers / some flowers and leaves we don't know") are becoming more common because of dryness, desertification, and the increase in Brandt's vole populations.

\section{Shrinking of plant roots}

Many herders mentioned damage to plant roots, especially in areas with loose soil, such as south-facing mountain slopes and sayrs. "Goats and horses are called undes khuudug mal [animals that chase the roots of plants], they dig plant roots from the ground, and as a result, plants have become sparse."

\section{Decrease of plant quality (species traits)}

Several herders said that the quality of rangeland plants is worsening, but "we do not know how much because we do not do research." Only one herder mentioned the quality of forest grass and a changing plant trait: the quality of Rhodiola rosea has decreased: "its root was sticky but now it is dry, not sticky."

\section{Change in shrub vegetation}

Many herders reported that shrub vegetation has not changed, because shrubs usually grow near or along forest edges, where livestock seldom graze. Several herders, however, said that some shrub patches have disappeared, particularly in valleys and flat areas. "Horses pulled out and ate bushes in winter." Livestock 
more often goes to bushes in Arbulag than in Khangai (because of more mosquitoes and flies in Khangai).

\section{Change in forest vegetation}

Many herders in both soums reported that forests have expanded and become denser. However, they added that "we don't always notice it precisely, because we live here all the time and trees are very long-lived plants, and forests change slowly." A few herders in Khangai soum said that "there were only 5-10 larch trees when I was a child, and now it has become a dense forest. The seeds fall to the ground, and saplings grow out of them."

In Arbulag soum, by contrast, many herders mentioned that forest areas have decreased and that forests are becoming sparser. The main reason is more intensive human utilization: "electric chain saws, trucks and laziness. In the past, the oxcarts were used to pick up logged trees and bring them out from the forest and during this process the oxcarts were small and slow enough not to damage the young trees not like the big trucks used now which smash all the young trees on their traces." No one reported forests growing sparser in Khangai soum.

A few herders in both soums said that there has been no noticeable change in forests, "only the thickness of trees is increasing." / "Forests will never shrink naturally unless people cut them down."

Some herders also mentioned other changes in forests, for example, a decrease in dry trees, twigs, and branches on the ground ("there were a lot when people cut the living wet trees"), and the recent cutting of high stumps left by earlier cuts.

Many herders in both soums reported that some forest patches dried up and died naturally because of the drought years, insect outbreaks, and the effect of wild animals ("deer rub their antlers against poplar and birch trees a lot when they are shedding their antlers"). Nobody cuts trees from such small forests because of local beliefs. "When I was a child, there were more than 30 [Larix] trees, but now they are old, eaten by insects, dried up and naturally rotten, so it looks like there are fewer. / Once people hear that you do not cut some trees, like many branched and shaman trees from here, they will never cut such trees, as well as never cutting trees at the forest edge, or in small forests."

\section{Change in the sayr and its vegetation}

All herders in Khangai soum said that the total area of sayr and sayr vegetation has changed. A few herders added that on sayrs, which are currently covered by vegetation, the river used to flow in the 1970s. In Arbulag soum, no one reported any change in the sayr.

\section{Changes in bare ground and rocks, erosion}

Many herders in both soums agreed that bare ground has increased and rocks have emerged, but only on south-facing slopes, because the soil there is easily eroded by drought, heavy rain, hail, spring flooding, and the effects of livestock (goats dig up roots), although the impact of goats was not too significant. A few herders argued that "the soil of the mountain slopes collapses due to heavy rain and hail but not livestock." Herders also observed that "if a place has thick topsoil, it will never open up."

15. Changes in the regeneration of abandoned yurt sites All herders mentioned that the regeneration time of abandoned yurt sites has increased in length. The soil "died" and turned black because oilskin was used instead of felt carpets. Most herders said that regeneration was faster in the past. Nowadays "in the first year bad weed plants grow, and [only] the next year will the soil improve and other plants grow."

\section{Change in vegetation type}

Only one herder in Arbulag soum said that the vegetation type is changing into another type. "The place with borog (species of Cyperaceae and Poaceae, which mostly grow in wet areas) is being replaced by botuul and the place with botuul by borog. But I heard that the soil of the Earth must change naturally, as a person gets old and will have white hair. Jinjuul (Potentilla acaulis L.) should grow on south-facing mountain slopes, but it is now growing in the sudag (greener meadows in small flat valleys). And borog in the sudag is disappearing, and aging, now agi (Artemisia frigida Willd.) has grown in the sudag, I have never seen it before, absolutely agi must grow only in dry places. The red ants' nests have never existed in the sudag, now they are here." The reported reason was dryness.

\section{Decrease in permafrost}

A few herders in both soums reported that the permafrost has decreased to some extent because of climate change. "When digging a toilet, the permafrost was reached at $1 \mathrm{~m}$ below the surface, but now it is at $1.5 \mathrm{~m}$." But "we have nothing to say about it because we do not study it."

\section{Reduction of water in the landscape in general}

Many herders in both study areas reported that the water source and level of rivers have reduced since 1991 and 2000, respectively. Several herders added "there are not that big floods anymore" and some channels of large rivers have dried out, or the water was flowing underground because of the drought years. A few herders said that it was caused by the cutting of trees, in addition to dryness. But some rivers started to flow again from 2019 because of higher precipitation. Many herders said that if many wet trees are cut from a forest "the vegetation will change because the water in the area will decrease, because wet trees draw a lot of water from the soil."

\section{Changes in tussocks}

All herders reported that tussocks (small grassy hillocks in wetlands) have become black and no plant has grown on top of them since 2000 (since 1997). The reported reasons included the drought years, lack of moisture, and an increase in livestock numbers. Several herders argued that the main reason is drought and the second reason is overgrazing.

Several herders mentioned that tussocks now break easily, their size is decreasing, and some plants on them (like borog: Carex sp.) are disappearing. "The distance between tussocks has expanded because of the lack of water." A few herders said that there are no new tussocks developing and no place where tussocks have completely disappeared since their childhood. Only one herder showed us an area near his wintering place where tussocks have almost disappeared because of dryness and car tracks. He also said that "tussocks turned black in 1981, but they regenerated afterward, then tussocks started to become black again since 2003. But later they could not regenerate because now there are too many livestock." 


\section{Changes in rocks}

All herders stated that large rocks have never changed at all, but rocks might erode slightly because of the influence of wind and water. Only one herder added that "a big rock collapsed because of lightning and blocked the path we were on."

\section{Changes in soil}

Many herders in both soums reported that the soil in general is getting worse. The main reason was the increasing number of livestock, especially goats. Several herders mentioned "the soil and earth get old naturally when their nutrients become fewer." A few herders added that some soils near abandoned livestock corral areas "die," mostly caused by the impact of livestock and manure. "When I was little, the soil was rich in fertility. But now there is no such fertility."

\section{Changes in wildlife populations}

Many herders said that recently, for certain reasons and legal restrictions (ban of hunting since 2000, 2003), some wild animal species have increased slightly in number, e.g., buga (red deer, Cervus elaphus), khandgai (moose, Alces alces), and tarvaga (marmot, Marmota sibirica). Others added other drivers: penalties are high, while market prices are low.

All herders in Khangai soum said that Brandt's voles have proliferated greatly since 2015 , because of dry weather and degradation of the pastures. However, "the Brandt's vole declined significantly this year because some of our local bag (smallest administrative unit) members rested some pastures in order to reduce Brandt's vole numbers."

Several herders in both soums mentioned that the number of animals such as chono (wolf, Canis lupus), khüder (musk deer, Moschus moschiferus), red deer, üyen (least weasel, Mustela nivalis), solongo (mountain weasel, Mustela altaica), marmot, zuram (long-tailed ground squirrel, Urocitellus undulatus), kherem (red squirrel, Sciurus vulgaris), minj (beaver, Castor fiber), and bulga (mink, Neovison vison) are still becoming scarcer because of hunting: "In recent years, wolves have declined with the advent of fast cars and fast guns."

A few herders mentioned that some insects have decreased. For instance, khökh türüü (horsefly, Tabanus sp.), tsartsaa (grasshopper, Locusta sp.), and shalz (sheep ked, Melophagus ovinus), "which were a lot when we were kids." One herder said that ticks were reduced by various chemicals against diseases like scabies.

\section{Changes in the physical parameters of wild animals (traits)} Many herders in both soums mentioned that the body size of some wild animals, such as göröös (Siberian roe deer, Capreolus pygargus), gakhai (wild pig, Sus scrofa), and red deer, has decreased partly because of a reduction in the plants the animals feed on. For example, "in the past, there were deer with eight branched antlers, now we commonly see a deer with six or seven branched antlers."

\section{Changes in the physical parameters of livestock}

Herders referred to some changes in livestock that they attributed to landscape and pasture change. Many herders reported that the body size of livestock has become smaller, and "livestock was much fatter in the past." An older herder in Arbulag soum mentioned that the lifespan of livestock has diminished. "Cattle used to calve 21 or 22 times when I was young, and now cattle have a maximum of 10 calves. The 25 -year-old horse was said to have good teeth, it means middle aged, the age of 33, 34 was called old at that time. Now we consider a 17 - or 18-year-old horse as old."

Habitats that have altered the most or the least

According to herders, the following habitats have altered the most during the last decades: (1) south-facing slopes ("have more male grass" [mostly includes Festuca lenensis and Koeleria cristata]), its soil is easily eroded by livestock and rain"); (2) summer camp sites ("the pressure of livestock and human impact is the most severe"); and (3) tussocky areas ("more related to rain"). Moderately altered habitats were, (1) forests ("little grazing in summer because of flies and mosquitoes, and in autumn and winter because of wolves"); (2) shireg along streams ("high number of livestock"); and (3) north-facing slopes ("those parts have no palatable grass, mainly borog grows and grazing livestock numbers are relatively low"). Some habitats have altered very little or not at all: (1) tsaram ("less palatable grasslands above the timber line, only if there is $d z u d$ do we drive some livestock to tsaram"); (2) screes in the forest ("vegetation is sparse with hard bushes, animals cannot walk among the rocks"); and (3) forest edges with bushy vegetation ("have a lot of mosquitoes, livestock does not like to graze there, they mainly graze there in autumn").

\section{Regenerative successions (with no decadal trends)}

Herders also reported changes that have no dominant trend direction, but belong to regenerative cycles. In these cases, vegetation changes after a disturbance but regenerates to the previous state in a couple of years or decades.

\section{Regeneration of abandoned livestock corral sites}

All herders said that at first, it is mainly weeds that grow on or near abandoned places. Then, in the following three to four years, these plants reduce in number and are replaced by other species after the soil has regenerated: "only after the manure has compacted to the ground, become thinned by rainwater and the winds, and reached a level that can be a fertilizer on the ground." The period of regeneration depends on how long livestock has been there and how thick the manure was. "Areas that were only slightly overgrazed will recover in about one to two years."

26. Regeneration of other weedy areas

Many herders mentioned that weeds will grow first (1) in places that were destroyed by Brandt's vole ("nariin ovs cannot grow"); (2) on marmot burrows: "they look more green" (than the surroundings) because sharilj, hyag, and tsoorgono (Rheum undulatum L.) are more fertilized by urine and manure"; and (3) in patches on mountain slopes that were "desertified" (vegetation became sparser with more bare ground). After disturbance these sites regenerate.

\section{Regeneration of abandoned yurt sites (with felt carpets)}

All herders reported that the vegetation of abandoned yurt sites regenerates quickly. Herders used the expression "lifeless soil" (ukhmel hurs) for areas near the yurt at nomad camp sites or on abandoned yurt and livestock corral areas where the soil is "soiling back."

\section{Succession after forest fire}

Most herders reported that normally the same type of khar mod (larch) forest recovers after forest fires and the cutting of trees. Several herders in Arbulag soum mentioned that birch (Betula 
platyphylla) and some species of willow (red, white, Salix turanica, $S$. ledebouriana) grow in large quantities on burnt areas. Only two herders in Arbulag soum said that the forest soil structure changes after burning, with larch forests replaced by deciduous and other trees, while some plants such as hyag, öndör ulaan (Chamaenerion angustifolium (L.) Scop.), and mushrooms (red and white) grow; after these species are settled, as the soil is nourished, ulaan botuul (Festuca rubra L.), darsh (Vicia cracca L.), khökh manchin (Aconitum czekanovskyi Steinb.), and shar manchin (Aconitum barbatum Pers.) etc. will grow.

Many herders in Khangai soum said that dark green grass like hyag grows first, followed gradually by other plants. A few herders said that they have never observed burnt places closely.

Fluctuations of plant populations and other repetitive changes Besides trends and regenerative changes, herders mentioned changes that occur regularly without any general major change in the landscape (Table 2).

\section{Fluctuation of some plant populations}

Many herders mentioned plants that decline (or even disappear) in drought years but regenerate and regrow when there is enough rain and moisture. Several herders said that "if there is rain, everything regenerates naturally." In years of low biomass production or "after a drought year, male grass grows relatively poorly, and from the second year it increases again." Many herders reported that some species like sharilj, nariin yagaan (Primula nutans Georgi.) increase in the year after a drought.

\section{Fluctuation of some animal populations}

Brandt's vole spreads everywhere when grass becomes short and pastures degrade. Several herders added that grasshoppers are more common in dry years. According to herders, insects, birds, and ükher ogotno (pikas, Ochotona daurica) have no significant impact on the pasture except grasshoppers. Conversely, wild pig and red deer were mentioned as harmful for pastures, but their impact is minimal because red deer and pig density is low. Wild pigs dig out grass and plant roots only in or near forests.

\section{Change of the shores of large rivers and sayr}

All herders said that the shores of large rivers change regularly but the riverbanks of small streams do not change with floods. These small banks develop naturally ("created by nature"). There is little or no impact of livestock on these shores, though yaks trample and may destroy them. Most herders said that "in the year of poor pasture production, the sayr's stones seem to have increased, and the sayr is observed as normal in a good year."

\section{Damage to trees and branches}

A few herders in Arbulag soum said that if there is a lot of wet snow in autumn, this damages trees. "Winter snow has no (such) effect."

\section{Some worldview elements underpinning the perception and interpretation of landscape changes}

Mongolian herders were speaking about nature as being an active agent, helping herders in their life. Worldview elements mentioned related to landscape change were, (1) nature provides water, air, pastures, etc., as well as knowledge how to use these resources properly; (2) nature regenerates (though slowly) forage grasses from year to year but also overgrazed pastures and cut forests; and (3) in disturbed sites, with time, nature replaces weeds with good forage grasses. The relationship with nature was reported as reciprocal, and herders felt responsibility for nature.

All herders said that "nature gives us everything" ("except love and children," one herder added), like water, air, plants, life, and so on. One herder said that "absolutely, nature takes care of our livestock because livestock live on the benefits of natural resources, even nature teaches us how to live and adapt. Herders live under the control of nature." They argued that nature, herders, and livestock are inextricably linked, "nobody can understand them separately. Livestock eat fresh and healthy grass in nature, people who consume the meat of healthy animals would be healthy."

All herders said that with time, everything in nature changes because of various factors. Nature always regenerates pastures and forests by itself "if there is enough rain, albeit slowly. If we can save and protect it, there is nothing else we can do. / All we can (actually must) do to help nature is to use everything properly, appropriately. / People should not pollute nature and water, cut many trees, dig into the soil or do mining, and they should prevent fires." A few herders added that we can help nature "by planting trees and shrubs," though it is rarely done in this region because "we have trees naturally in abundance." Peace was mentioned several times: "we will have peace as long as people and livestock have water to drink, grass to eat, pastures to graze, and the livestock is fat and full." They recalled a Mongolian saying: "if the lake is peaceful, the duck will be peaceful."

Some herders also said that "nature cleans itself. Sharilj and other weeds grow mainly on abandoned livestock corral areas. These plants are not eaten by livestock. If such a place were not used for one or two years, these weeds would be replaced by other, more useful plants. In other words, nature cleans itself. Nature cleans itself also in burnt forests" (grasses and trees regenerate).

\section{Herders' suggestions for reversing adverse changes in the landscape}

All herders (often spontaneously during the interviews and landscape walks) suggested that the best solution against pasture degradation is the resting of pastures for at least three to four months (even from 15 August until the following June) or ideally for a whole year: "it will regenerate and grow well." Other suggestions by several herders were to reserve some pastures for hard times, especially spring and winter, as well as to use distant pastures (make an otor) under normal conditions, i.e., on warm days in winter and when there is less snow and fewer nearby reserve pastures for bad days. According to all herders, increasing mobility is the key: "A stupid man moving is better than a wise man sitting," they said. On the other hand, herders never mentioned any management or practice to improve or intensify their pastures, such as manuring (only very rarely and locally around pens), overseeding with nutritional or cultivated grasses, burning, and replantation of onion or other plant species. They all argued in favor of the need to rely on spontaneous natural regeneration of overused pastures ("nature regenerates itself").

Many herders emphasized that appropriate livestock numbers would be needed, and a better structure of livestock, as well as good quality livestock (good breeds, healthy individuals). "We need livestock that are few, and of high quality. High numbers of livestock are difficult to herd and make the resting of pastures 
more difficult. They would be intolerant to $d z u d$, and there will not be enough pasture for them."

Several herders emphasized that otor and pasture resting require cooperation among herders, as individual families are incapable of organizing it alone because neighbors would use the area. "If I moved somewhere in order to rest my summer pasture, others would graze here so that I have no chance to rest it."

\section{DISCUSSION}

\section{Perception of landscape changes: trends, regenerations, and fluctuations}

We found 32 indicators for the 14 habitat types concerning how herders perceived landscape changes. Herders had deep knowledge of their landscape, and they attributed various changes to diverse drivers on their grasslands, wetlands, and forests (Figs. 3-5).

Mongolian herders monitored the structure of vegetation, and the height, density, and quantity of several dominant and useful plant species. Some indicators of the long-term trends reported by herders are already well-known in case studies in Mongolia and around the world: worsening of rangeland production (Bruegger et al. 2014, Hilker et al. 2014, Fernández-Giménez et al. 2016, Molnár 2017, Levine et al. 2019), lower hay production (Lkhagvadorj 2013b), shorter and sparser grass, decreasing species richness (Chognii 2001, Hobbs et al. 2014, Molnár 2017), an increase in bare ground and weeds (Fernández-Giménez and Allen-Diaz 1999, Chognii 2001, Mapinduzi et al. 2003, Tuvshintogtokh and Ariungerel 2013), a decline in nariin ovs (palatable thin grass; Kakinuma and Takatsuki 2012), worsening quality of rangeland plants (Oba and Kaitira 2006), deteriorating water resources (Fassnacht et al. 2018), and change in permafrost (Kynický et al. 2009). Increasing populations of pests, such as Brandt's vole, are known to decrease species richness, vegetation cover, and availability of the main forage species (Chognii 2001, Cui et al. 2020). Herders' perceptions of forest changes were consistent with the results of ecologists and foresters, apart from the reported expansion of forest, which seems to be a local phenomenon. In Mongolia, the area of forest is gradually decreasing because of climate warming, particularly in grasslanddominated areas, because small forest patches are more vulnerable to climate warming than large continuous forests (Dulamsuren et al. 2010, Khansaritoreh et al. 2017).

Herders had detailed observations about certain plant species, though they only explicitly mentioned a relatively low number of species ( 24 species, see Table 3 ). The species mentioned were wild food plants, important medicinal, or key forage species, which are widespread in these landscapes and have long been commonly used by herders year after year (Sanchir et al. 2003, Ligaa et al. 2009). Herders were also knowledgeable about the drivers responsible for these population changes. Additionally, they noticed newly appeared species, although they did not closely monitor changes in species composition per se at the patch or habitat type level (see also the conclusions of Babai and Molnár 2014). An interesting indicator we found is that herders use changes in the body size and body parameters of livestock and wild game as indicators of rangeland production and forage quality change (cf. Oba and Kotile 2001, Reed and Dougill 2002, Levine et al. 2019).
The understanding of landscape and pasture changes by traditional Mongolian herders has also been studied by Fernández-Giménez (1993, 2000, 2015a), Kakinuma et al. (2014), and Fernández-Giménez et al. (2018). It is a general understanding that most of the indicators found are common between herders and scientists. The similarity of many indicators used by herders and scientists could contribute to a better integration of local knowledge and formal monitoring (Dabasso et al. 2012, Jamsranjav et al. 2019). Strengthening cooperation between traditional knowledge systems and ecological and social sciences was also promoted by the Intergovernmental Platform of Biodiversity and Ecosystem Services (Díaz et al. 2019). It seems that in the case of Mongolian rangelands, this cooperation has good foundations.

Furthermore, herders in both soums mentioned similar indicators, which suggests that these indicators may be adapted for use beyond the studied regions (cf. Oba 2012). However, the limited attention paid by herders to changes in species composition, as well as differences in emphasis on keystone species, may hamper the exchange of knowledge between herders and scientists (Molnár et al. 2016a, 2020, Ulicsni et al. 2020).

No contradicting perception of indicators was found. This was slightly unexpected because in other regions of the world, locals and scientists/conservationists often perceive changes differently (Reed et al. 2008, Molnár et al. 2016a, Thurstan et al. 2016, Ujházy et al. 2020). One explanation could be that the traditional and the rangeland scientific understandings of proper pasture and forest management strongly overlap in Mongolia, and state regulations seldom compromise traditional practices (see the work of Sambuu 1987).

We found a few trends and indicators, however, that are only rarely mentioned in the scientific and traditional knowledge literature, if at all, for example, changes in tussocks (blackening of their heads), slower regeneration of abandoned yurt sites since oilskin has been used on the floor, and changes in the ground layer vegetation of forests. Adverse changes in tussocky areas are impacting livelihoods because these areas often provide relatively good pastures close to summer and autumn camp sites (Gantuya et al. 2019).

Conversely, herders never mentioned certain trends that are often documented by scientists. For example, herders rarely (or never) mentioned species diversity, changes in the type of plant community, endemic and protected species, and of course indicators derived from satellite imagery (Hilker et al. 2014).

In our understanding, herders often just remembered changes ("We do not notice changes because we live here, we do not look, we do not study it.”). Knapp and Fernández-Giménez (2009) also note that the focus of local land-users on shorter term changes may impact their ability to perceive gradual landscape changes because of their continuous contact with the local nature. Herders regularly referred to the long-term stability of their landscape, and the slow changes in its vegetation (see also Gantuya et al. 2019). Regarding climate change, we have evidence that catastrophic or extreme events can strengthen the feeling of change, while gradual changes may remain hidden (Marin 2010). Furthermore, the way in which herders perceive landscape change is always complex. When they report a change, they also include 
Fig. 3. Herders' observations of long-term landscape and vegetation changes during recent decades in Khangai and Arbulag soums, Mongolia. Numbers of relevant indicators is shown in brackets. Photos: Ábel Péter Molnár.

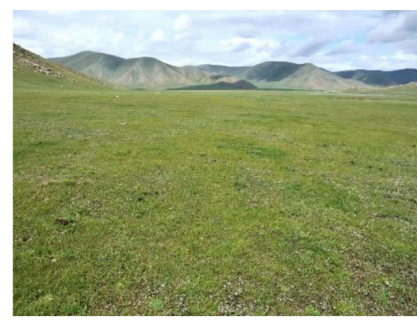

According to herders in overgrazed areas in both soums, production decreased, plants dwarfed, and the number of species decreased. In the past: grass reached up to $50 \mathrm{~cm} / \mathrm{up}$ to a horse's hopple, it was impossible to see a one-year-old calf. $[1,5]$

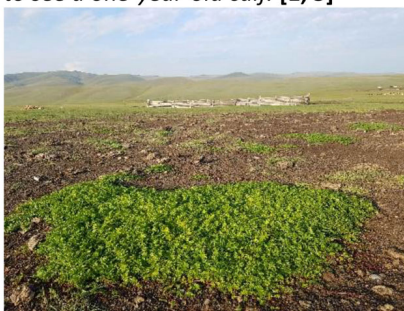

Weeds, pests (e.g., Brandt's vole) and some previously unknown plants have increased, soil dies more around livestock corrals. In the past, there was no talk about weeds growing or increasing and now weeds and bad plants are growing more. $[\mathbf{7}, \mathbf{8}, \mathbf{2 1}]$

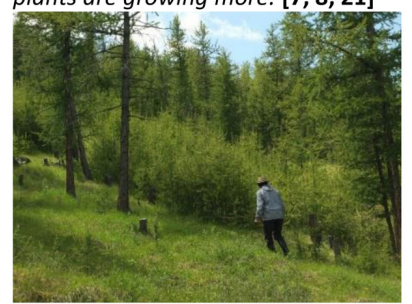

Forests have expanded and become denser in Khangai and changed little in Arbulag. The number of young trees has increased recently. There are old trees deep in the forest and new ones at the edges. It means that the forest is expanding. [12]

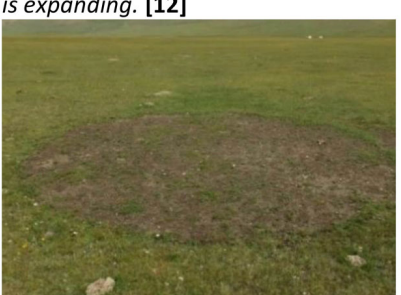

The soil of recently abandoned yurt sites has become totally dead. When locals used felt carpet in the yurt, regeneration was quick. 1-2 years were enough for a full recovery, but nowadays regeneration takes at leas 3-4 years. [15]

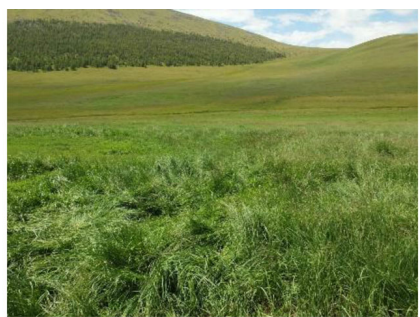

The area and quantity of good hay have decreased, but grass quality has not changed. The hay grass reached up the stirrup and there were many available areas to make hay in the past. [2]

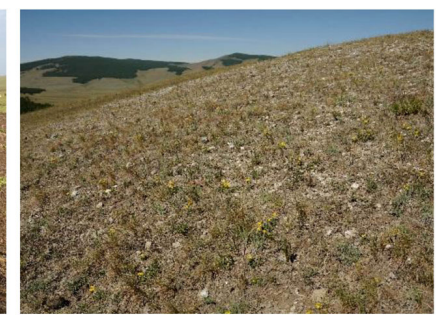

Some valuable species have declined, nariin ovs (e.g., Festuca lenensis) could not grow because strange flowers leaves, weeds, short-lived flowers grow a lot in drought years, and goats and horses dig out their roots especially in winter and early spring. $[6,8]$

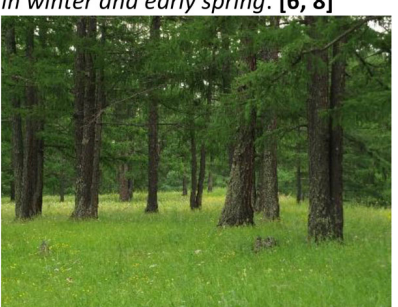

The density of dead dry trees and branches on the ground has decreased. Because there was no forest fire in the last 30-40 years, and (recently) we do not cut wet and living trees, only dry trees. [12]

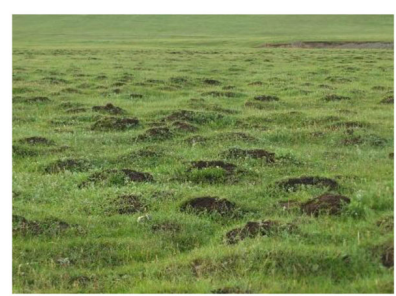

The heads of the tussocks have turned black and tussock size has decreased. In the past they were full of bundled grass and now the grass is no longer growing (on the top). Tussocks were as big as a camel's hump / slightly above the knee. [19]

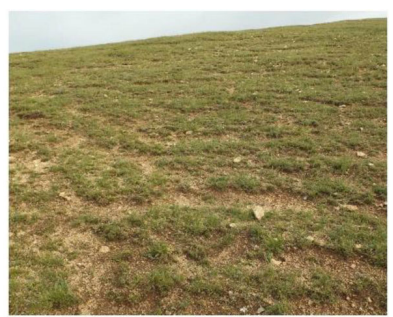

Vegetation has become sparse, bare ground has increased, some valuable species have decreased. South-facing mountain slopes become sparse most easily, because they always have less snow, more palatable grass, and mostly sandy soil. [4, 6, 14, ]

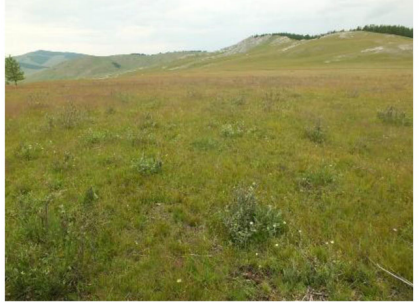

Shrub vegetation has remained stable or decreased due to drought, flooding, and increasing livestock numbers. Some shrubs (shrub patches) flow into the river, freeze in winter, and disappear completely. [11]

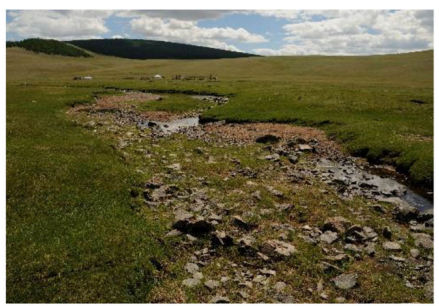

The landscape in general has been growing drier and the permafrost has sunk. Some small rivers, streams, and wells have dried up completely, there was no such shortage of water in the past. River water levels have decreased, and sayrs have widened. $[13,17,18]$

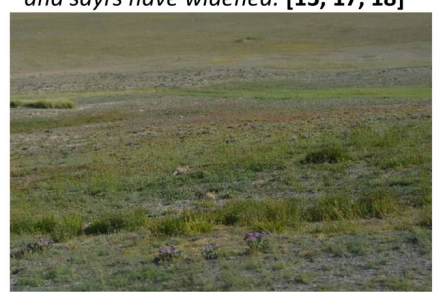

Most wild mammal species have decreased in recent decades, though there has lately been some recovery in the case of marmot, wolf, and red deer. Also, the bodies of some wild animals and livestock are becoming smaller, and they are easily exposed to diseases and parasites. [22, 23, 24] 
Fig. 4. Herders' observations of different types of recurrent regenerative successions in Khangai and Arbulag soums, Mongolia. Numbers of relevant indicators is shown in brackets. Photos: Ábel Péter Molnár.

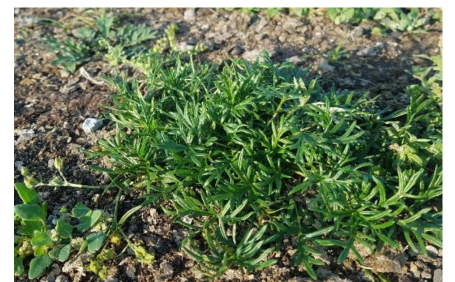

Regeneration of abandoned animal rest places. Sharilj, hyag, and tsagaan luuli mainly grow first on or near abandoned places. If it is not used for 3-4 years, good (=nariin ovs) grasses will grow. [25]

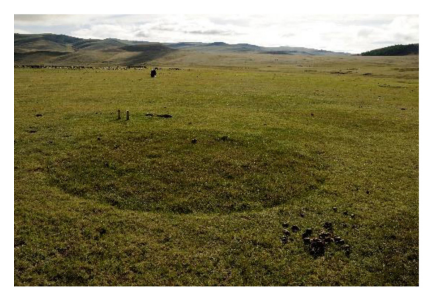

Regeneration of abandoned yurt sites. When
we use felt carpet in the yurt, the plants grow easily after 1 year. [27]

other (somehow) related changes; changes are interrelated, so general trends are often unclear. In both study areas, however, the slow, long-term worsening of pasture conditions was a general trend.

\section{Key drivers of changes}

The key drivers reported by herders were drought and increasing livestock numbers (cf. Bruegger et al. 2014, Khishigbayar et al. 2015). Herders argued that anthropogenic drivers accelerated after 1990 , especially in the last $10-15$ years. There was a variety of explanations, however: for example, some herders emphasized only the impact of drought, while others emphasized livestock numbers, or both. Fernández-Giménez (1993) and Fernández-Giménez et al. (2015a) also found that herders may attribute pasture degradation exclusively to drought (with little or no impact of livestock). Similar explanations have been documented among Hungarian herders (Molnár 2012). Recently, however, more complex explanations have also been found among herders, including grazing pressure and herd composition (on a similar change in Hungary: Molnár 2014, Molnár et al. 2016b). The perception of the importance of drivers may have changed because herders nowadays are more connected to the internet, TV, and other top-down information sources that provide scientific information on the impact of increasing livestock numbers on Mongolian pastures (Seid et al. 2016, Amadi et al. 2018). In some cases, differences in the explanations given by herders were due to differences in the two study areas (e.g., forest structure, dynamics of sayr, trends of Allium altaicum) as well as personal differences. The change in vegetation type, for example, which is a rare situation in the stable Mongolian landscape, was
Fig. 5. Herders' observations of multi-year fluctuations in various habitats in Khangai and Arbulag soums, Mongolia. Numbers of relevant indicators is shown in brackets. Photos: Ábel Péter Molnár.

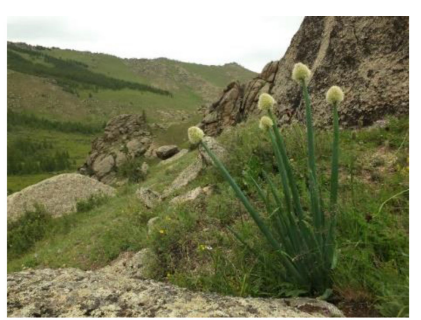

Allium altaicum, Ribes altissimum, and Lonicera altaica grow smaller and produce fewer fruits in drought years, and grow better in wetter years. Some weeds such as sharilj increase in the year after a drought. [29]

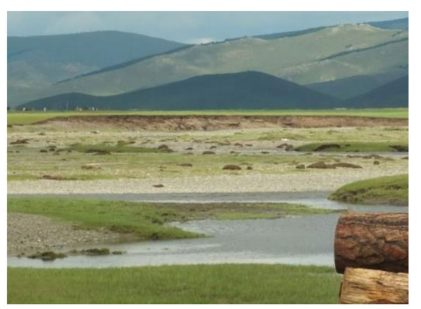

The shores of large rivers constantly change, collapse, and develop during major floods. If a river floods, plants are taken away with their roots, water flows in different directions, and sayr develops (or disappears). [31]

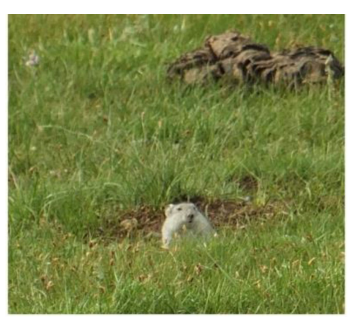

Some animal species also fluctuate with drought and rain. If it rains a lot, the grass grows high and üliin tsagaan ogotno (Brandt's vole) naturally reduces. [30]

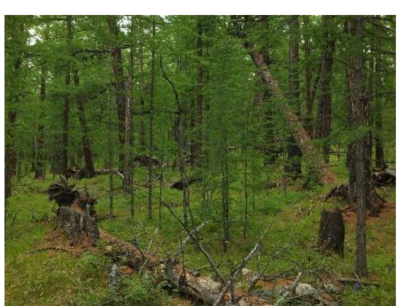

If there is wet snow in autumn (midAugust to early September), some trees or their branches (even thick ones) may break and fall. [32] mentioned only by a single herder, who was one of the most experienced informants. He attributed this change to the longterm impact of droughts.

\section{Possible solutions to address adverse changes}

Herders were aware that many ( half) of the changes they observed indicated degradation of their pastures and forests. In the Mongolian worldview, "nature gives you everything" that is needed for life (Avar 2012).

Based on their worldviews, personal experiences, values, or relationships to nature, multiple stakeholders can perceive landscape changes differently (Bennett 2016). For example, herders all over the world strongly believe that nature, everything in nature, should be in balance, people have to love and use nature properly, including soil, water, trees, and pastures (Shen and Tan 2012, Jandreau and Berkes 2016, Kis et al. 2017). Mongolian herders aim to live in harmony with nature (they value harmony) and to understand how nature functions, and they would like to cooperate with her. They do not fight against nature, but prefer to adapt and aim for no change; indeed they are afraid of change. They believe that, if there is a change in nature, then something must be wrong, and only people do bad things (Avar 2012). They also stated that we "herders live under the control of nature." They do not feel they have the right to move species in the 
landscape (e.g., wild onion from one slope to another, or vansemberüü (Saussurea involucrata; Norris et al. 2020). Herders always emphasized that you are expected to help nature to regenerate herself (overused pastures) and to clean herself (from weeds). If you do so, nature will continue to give you "everything." Herders' behavior and solutions to reverse changes mirror these values, perceptions, and beliefs. Our results show that relational values (Chan et al. 2016) play a significant role in shaping herders' perception and behavior, and herders act as landscape stewards in their environment (Raymond et al. 2016).

Mongolian grasslands, though changing, are still resilient (Scharf et al. 2010, Densambuu et al. 2018); they have very slow dynamics during both degradation and regeneration (Gunin et al. 1999). Landscape-level changes of the habitat mosaics are also slow compared to European and North American areas (cf. Biró et al. 2013, 2018, Holsinger et al. 2019, Wang et al. 2020). The Mongolian landscape is and is perceived as more or less stable. The same is true for our study areas: habitats change, but change is slow. The moderately degraded grasslands in these mountain forest-steppes were not (yet) invaded by non-native weeds, only local, disturbance-tolerant species increased, while diversity of both species and habitats is still relatively high (Gantuya et al. 2019). Herders had a similar understanding about the speed of change and the role of native "newly" arriving species.

Traditional Mongolian pasture utilization focuses on natural regeneration (Sambuu 1987, Chognii 2001), and only marginally on intensification. Herders suggested increasing mobility to achieve a more homogenous utilization of pastures and the resting of pastures as the best solutions for reversing adverse changes (In Africa, Oba and Kaitira 2006; In Mongolia, Fernández-Giménez et al. 2018). Everything changes but slowly, and there is a sense of eternity (tussocks, rocks, mountains, forests, and springs were born long ago, they say; Gantuya et al. 2019). Biomass manipulation (e.g., grassland and forest management) has little chance of success, while adaptation to uncertainty is essential for long-term survival (Fernández-Giménez et al. 2015a).

Recently, Fernández-Giménez and her research group have studied sustainable ways of rangeland utilization (key possibilities being increasing mobility, e.g., otor, pasture resting and preparation for $d z u d$; Fernández-Giménez et al. 2015a, Jamsranjav et al. 2019). They found that cooperation between local herders improves both livelihoods and pasture conditions (Addison et al. 2013, Ulambayar et al. 2017). Herders in our study areas also repeatedly emphasized the need for better local and regional cooperation. The number of herders who wish to maintain and improve the conditions of their pastures by cooperation is generally on the increase throughout Mongolia. By 2018, 830 pasture user groups (PUGs) in 11 provinces had signed pasture use agreements with soum governors. In other words, about 15,000 herder households are working to ensure the implementation of the pasture improvement agreement, in order to manage the use of 16 million hectares of pastureland (Densambuu et al. 2018). Scharf et al. (2010) argue that the efficiency of top-down regulations of reserve pastures, wildlife conversation, etc., could be improved with greater involvement of soum governments and local herder groups. To achieve this, integrated regulations would be needed that include (1) strengthening property rights and entitlements, (2) developing community-based natural resource management, and (3) increasing the effectiveness of rangeland management through local governance (Scharf et al. 2010).

In conclusion, we found that herders have a deep understanding of landscape and vegetation change (32 indicators of decadal trends, regenerative successions, and fluctuations). Their ecological understanding has many common elements with scientific understanding, especially about forage production and its drivers. Herders were aware of the adverse impacts caused by climate change and increased livestock numbers. To combat these impacts, Mongolian herders wish to cooperate especially with each other in order to increase mobility (for a more homogenous utilization of pastures), stop overgrazing, and allow nature to regenerate their pastures (pasture resting). We found a nuanced, reliable, and widely shared understanding of landscape and vegetation changes, which may contribute to fruitful cooperation with decision makers and scientists. Because grazing is the only viable (and sustainable) option for utilizing Mongolian grasslands, both top-down and bottom-up decision making need to promote proper utilization, including helping nature to regenerate degraded pastures.

\section{Responses to this article can be read online at: https://www.ecologyandsociety.org/issues/responses. php/12454}

\section{Acknowledgments:}

We gratefully thank all the Mongolian herders of the Khangai soum, Arkhangai province and Arbulag soum, Khuvsugul province, who patiently and generously shared their knowledge with us.

This research was supported by the projects of the National Research, Development and Innovation Office "Fine-scale landscape ecology: linking vegetation change with interacting indirect and direct drivers using traditional ecological knowledge and oral history" [NKFIH K 131837] and "Sustainable use of ecosystem services - research for mitigating the negative effect of climate change, land use change and biological invasion" [GINOP-2.3.2-15-2016-00019]. Dániel Babai was supported by the MTA Premium Postdoctoral Research Program of the Hungarian Academy of Sciences [grant number: PPD008/2017].

\section{Data Availability:}

The data that support the findings of this study are available on request from the corresponding author, [BG]. The data are not publicly available because of cultural sensitivity.

\section{LITERATURE CITED}

Addison, J., J. Davies, M. Friedel, and C. Brown. 2013. Do pasture user groups lead to improved rangeland condition in the Mongolian Gobi Desert? Journal of Arid Environments 94:37-46. https://doi.org/10.1016/j.jaridenv.2013.02.009

Amadi, J. A., D. O. Olago, G. O. Ong'amo, S. O. Oriaso, I. K. Nyamongo, and B. B. Estambale. 2018. "We don't want our clothes to smell smoke": changing malaria control practices and 
opportunities for integrated community-based management in Baringo, Kenya. BMC Public Health 18(1):609. https://doi. org/10.1186/s12889-018-5513-7

Angassa, A., and F. Beyene. 2003. Current range condition in southern Ethiopia in relation to traditional management strategies: the perceptions of Borana pastoralists. Tropical Grasslands 37(1):53-59.

Angerer, J., G. Han, I. Fujisaki, and K. Havstad. 2008. Climate change and ecosystems of Asia with emphasis on Inner Mongolia and Mongolia. Rangelands 30(3):46-51. https://doi.org/10.2111/1551-501X (2008)30[46:CCAEOA]2.0.CO;2

Avar, Á. 2012. A természet és az állatok a hagyományos mongol gondolkodásban. [Nature and animals in the traditional Mongolian worldview]. Equinter, Budapest, Hungary.

Babai, D., and Z. Molnár. 2014. Small-scale traditional management of highly species-rich grasslands in the Carpathians. Agriculture, Ecosystems and Environment 182:123-130. https:// doi.org/10.1016/j.agee.2013.08.018

Babai, D., A. Tóth, I. Szentirmai, M. Biró, A. Máté, L. Demeter, M. Szépligeti, A. Varga, Á. Molnár, R. Kun, and Z. Molnár. 2015. Do conservation and agri-environmental regulations effectively support traditional small-scale farming in East-Central European cultural landscapes? Biodiversity and Conservation 24 (13):3305-3327. https://doi.org/10.1007/s10531-015-0971-z

Bennett, N. J. 2016. Using perceptions as evidence to improve conservation and environmental management. Conservation Biology 30(3):582-592. https://doi.org/10.1111/cobi.12681

Berkes, F. 2017. Sacred ecology. Fourth edition. Routledge, New York, New York, USA.

Berkes, F., J. Colding, and C. Folke. 2000. Rediscovery of traditional ecological knowledge as adaptive management. Ecological Applications 10(5):1251-1262. https://doi.org/10.1890/1051-0761 (2000)010[1251:ROTEKA]2.0.CO;2

Bestelmeyer, B. T., A. Ash, J. R. Brown, B. Densambuu, M. Fernández-Giménez, J. Johanson, M. Levi, D. Lopez, R. Peinetti, L. Rumpff, and P. Shaver. 2017. State and transition models: theory, applications, and challenges. Pages 303-345 in D. D. Briske, editor. Rangeland systems. Springer, Cham, Switzerland. https://doi.org/10.1007/978-3-319-46709-2 9

Bieling, C. 2013. Perceiving and responding to gradual landscape change at the community level: insights from a case study on agricultural abandonment in the Black Forest, Germany. Ecology and Society 18(2):36. http://dx.doi.org/10.5751/ES-05590-180236

Biró, M., J. Bölöni, and Z. Molnár. 2018. Use of long-term data to evaluate loss and endangerment status of Natura 2000 habitats and effects of protected areas. Conservation Biology 32 (3):660-671. https://doi.org/10.1111/cobi.13038

Biró, M., B. Czúcz, F. Horváth, A. Révész, B. Csatári, and Z. Molnár. 2013. Drivers of grassland loss in Hungary during the post-socialist transformation (1987-1999). Landscape Ecology 28 (5):789-803. https://doi.org/10.1007/s10980-012-9818-0

Bruegger, R. A., O. Jigjsuren, and M. E. Fernández-Gimenez. 2014. Herder observations of rangeland change in Mongolia: indicators, causes, and application to community-based management. Rangeland Ecology and Management 67 (2):119-131. https://doi.org/10.2111/REM-D-13-00124.1

Bürgi, M., A. M. Hersperger, and N. Schneeberger. 2005. Driving forces of landscape change-current and new directions. Landscape Ecology 19(8):857-868. https://doi.org/10.1007/s10980-005-0245-3

Chan, K. M., P. Balvanera, K. Benessaiah, M. Chapman, S. Díaz, E. Gómez-Baggethun, R. Gould, N. Hannahs, K. Jax, S. Klain, et al. 2016. Opinion: Why protect nature? Rethinking values and the environment. Proceedings of the National Academy of Sciences 113(6):1462-1465. https://doi.org/10.1073/pnas.1525002113

Chognii, O. 2001. The feature of regeneration grassland with using nomadic grazing in Mongolia [Title translated from the Mongolian]. Mongol Sudlal, Ulaanbaatar, Mongolia.

Cui, C., Y. Xie, Y. Hua, S. Yang, B. Yin, and W. Wei. 2020. Brandt's vole (Lasiopodomys brandtii) affects its habitat quality by altering plant community composition. Biologia 75:1097-1104. https:// doi.org/10.2478/s11756-020-00469-z

Dabasso, B. H., G. Oba, and H. G. Roba. 2012. Livestock-based knowledge of rangeland quality assessment and monitoring at landscape level among borana herders of northern Kenya. Pastoralism: Research, Policy and Practice 2(1):2. https://doi. org/10.1186/2041-7136-2-2

Densambuu, B., S. Sainnemekh, B. Bestelmeyer, and U. Budbaatar. 2018. National report on the rangeland health of Mongolia: second assessment. Green Gold-Animal health project, SDC, Mongolian National Federation of PUGs. Ulaanbaatar, Mongolia.

Díaz, S. M., J. Settele, E. S. Brondízio, H. T. Ngo, M. Guèze, J. Agard, A. Arneth, P. Balvanera, K. A. Brauman, S. H. M. Butchart, K. M. A. Chan, L. A. Garibaldi, K. Ichii, J. Liu, S. M. Subramanian, G. F. Midgley, P. Miloslavich, Z. Molnár, D. Obura, A. Pfaff, S. Polasky, A. Purvis, J. Razzaque, B. Reyers, R. Roy Chowdhury, Y. J. Shin, I. J. Visseren-Hamakers, K. J. Willis, and C. N. Zayas. 2019. IPBES: Summary for policymakers of the global assessment report on biodiversity and ecosystem services of the Intergovernmental Science-Policy Platform on Biodiversity and Ecosystem Services. IPBES Secretariat, Bonn, Germany.

Du, C., M. Shinoda, K. Tachiiri, B. Nandintsetseg, H. Komiyama, and S. Matsushita. 2018. Mongolian herders' vulnerability to dzud: a study of record livestock mortality levels during the severe 2009/2010 winter. Natural Hazards 92(1):3-17. https://doi.org/10.1007/s11069-017-2893-4

Dulamsuren, C., M. Hauck, M. Khishigjargal, H. H. Leuschner, and C. Leuschner. 2010. Diverging climate trends in Mongolian taiga forests influence growth and regeneration of Larix sibirica. Oecologia 163(4):1091-1102. https://doi.org/10.1007/s00442-010-1689$\mathrm{y}$

Environmental Systems Research Institute (ESRI). 2012. ArcGIS.10.1. ESRI, Redlands, California.

Fassnacht, S. R., A. M. Allegretti, N. B. Venable, M. FernándezGiménez, S. Tumenjargal, M. Kappas, M. J. Laituri, B. Batbuyan, and A. K. Pfohl. 2018. Merging indigenous knowledge systems and station observations to estimate the uncertainty of 
precipitation change in Central Mongolia. Hydrology 5(3):46. https://doi.org/10.3390/hydrology5030046

Fernández-Giménez, M. E. 1993. The role of ecological perception in indigenous resource management: a case study from the Mongolian forest-steppe. Nomadic Peoples 33:31-46.

Fernández-Giménez, M. E. 1999a. Reconsidering the role of absentee herd owners: a view from Mongolia. Human Ecology 27 (1):1-27. https://doi.org/10.1023/A:1018757632589

Fernández-Giménez, M. E. 1999b. Sustaining the steppes: a geographical history of pastoral land use in Mongolia. Geographical Review 89(3):315-342. https://doi.org/10.1111/ j.1931-0846.1999.tb00222.x

Fernández-Giménez, M. E. 2000. The role of Mongolian nomadic pastoralists' ecological knowledge in rangeland management. Ecological Applications 10(5):1318-1326. https:// doi.org/10.1890/1051-0761(2000)010[1318:TROMNP]2.0.CO;2

Fernández-Giménez, M. E., and B. Allen-Diaz. 1999. Testing a non-equilibrium model of rangeland vegetation dynamics in Mongolia. Journal of Applied Ecology 36(6):871-885. https://doi. org/10.1046/j.1365-2664.1999.00447.x

Fernández-Giménez, M. E., G. R. Allington, J. Angerer, R. S. Reid, C. Jamsranjav, T. Ulambayar, K. Hondula, B. Baival, B. Batjav, T. Altanzul, and Y. Baasandorj. 2018. Using an integrated social-ecological analysis to detect effects of household herding practices on indicators of rangeland resilience in Mongolia. Environmental Research Letters 13(7):075010. https://doi. org/10.1088/1748-9326/aacf6f

Fernández-Giménez, M. E., J. P. Angerer, A. M. Allegretti, S. R. Fassnacht, A. Byamba, J. Chantsallkham, R. Reid, and N. B. H. Venable. 2015b. Integrating herder observations, meteorological data and remote sensing to understand climate change patterns and impacts across an eco-climatic gradient in Mongolia. Pages 228-234 in M. E. Fernández-Giménez, B. Baival, S. R. Fassnacht, and D. Wilson, editors. Building resilience of Mongolian rangelands: a trans-disciplinary research conference. Nutag Action and Research Institute, Ulaanbaatar, Mongolia

Fernández-Giménez, M. E., B. Batkhishig, B. Batbuyan, and T. Ulambayar. 2015a. Lessons from the dzud: community-based rangeland management increases the adaptive capacity of Mongolian herders to winter disasters. World Development 68:48-65. https://doi.org/10.1016/j.worlddev.2014.11.015

Fernández-Giménez, M. E., N. H. Venable, J. Angerer, S. Fassnacht, and K. Jamyansharav. 2016. Ecological-cultural feedbacks in Mongolian social-ecological systems. Pages 515-517 in A. Iwaasa, H. A. (B.) Lardner, W. Willms, M. Schellenberg, and K. Larson, editors. Proceedings of the $X$ International Rangeland Congress. Saskatoon, Saskatchewan, Canada.

Fernández-Giménez, M. E., N. H. Venable, J. Angerer, S. R. Fassnacht, R. S. Reid, and J. Khishigbayar. 2017. Exploring linked ecological and cultural tipping points in Mongolia. Anthropocene 17:46-69. https://doi.org/10.1016/j.ancene.2017.01.003

Galvin, K. A. 2009. Transitions: pastoralists living with change. Annual Review of Anthropology 38:185-198. https://doi. org/10.1146/annurev-anthro-091908-164442
Gantuya, B., Á. Avar, D. Babai, Á. Molnár, and Z. Molnár. 2019. "A herder's duty is to think": landscape partitioning and folk habitats of Mongolian herders in a mountain forest steppe (Khuvsugul-Murun region). Journal of Ethnobiology and Ethnomedicine 15(1):54. https://doi.org/10.1186/s13002-019-0328$\underline{\mathrm{X}}$

Gunin, P. D., E. A. Vostokova, N. I. Dorofeyuk, P. E. Tarasov, and C. C. Black. 1999. Vegetation dynamics of Mongolia. Vol. 26. Springer, Dordrecht, The Netherlands. https://doi. org/10.1007/978-94-015-9143-0

Hilker, T., E. Natsagdorj, R. H. Waring, A. Lyapustin, and Y. Wang. 2014. Satellite observed widespread decline in Mongolian grasslands largely due to overgrazing. Global Change Biology 20 (2):418-428. https://doi.org/10.1111/gcb.12365

Hobbs, J. J., K. Krzywinski, G. L. Andersen, M. Talib, R. H. Pierce, and A. E. Saadallah. 2014. Acacia trees on the cultural landscapes of the Red Sea Hills. Biodiversity and Conservation 23 (12):2923-2943. https://doi.org/10.1007/s10531-014-0755-X

Holsinger, L., S. A. Parks, M. A. Parisien, C. Miller, E. Batllori, and M. A. Moritz. 2019. Climate change likely to reshape vegetation in North America's largest protected areas. Conservation Science and Practice 1(7):e50. https://doi. org/10.1111/csp2.50

Huntington, H. P. 2000. Using traditional ecological knowledge in science: methods and applications. Ecological Applications 10 (5):1270-1274. https://doi.org/10.1890/1051-0761(2000)010[1270: UTEKIS]2.0.CO;2

Ingold, T. 2000. The perception of the environment: essays on livelihood, dwelling and skill. Routledge, London, UK. https://doi. org/10.4324/9780203466025

International Society of Ethnobiology (ISE). 2006. ISE Code of Ethics (with 2008 additions). ISE, University of Florida, Gainesville, Florida, USA.

Jamsranjav, C., M. E. Fernández-Giménez, R. S. Reid, and B. Adya. 2019. Opportunities to integrate herders' indicators into formal rangeland monitoring: an example from Mongolia. Ecological Applications 29(5):e01899. https://doi.org/10.1002/ eap.1899

Jandreau, C., and F. Berkes. 2016. Continuity and change within the social-ecological and political landscape of the Maasai Mara, Kenya. Pastoralism 6:1. https://doi.org/10.1186/s13570-016-0048y

Johnson, D. A., D. P. Sheehy, D. Miller, and D. Damiran. 2006. Mongolian rangelands in transition. Science et Changements Planétaires/Sécheresse 17(1):133-141.

Kakinuma, K., T., Sasaki, U. Jamsran, T. Okuro, and K. Takeuchi. 2014. Relationship between pastoralists' evaluation of rangeland state and vegetation threshold changes in Mongolian rangelands. Environmental Management 54:888-896. https://doi. org/10.1007/s00267-014-0341-8

Kakinuma, K., and S. Takatsuki. 2012. Applying local knowledge to rangeland management in northern Mongolia: do 'narrow plants' reflect the carrying capacity of the land? Pastoralism: Research, Policy and Practice 2:23. https://doi.org/10.1186/2041-7136-2-23 
Khansaritoreh, E., C. Dulamsuren, M. Klinge, T. Ariunbaatar, B. Bat-Enerel, G. Batsaikhan, K. Ganbaatar, D. Saindovdon, Y. Yeruult, J. Tsogtbaatar, D. Tuya, C. Leuschner, and M. Hauck. 2017. Higher climate warming sensitivity of Siberian larch in small than large forest islands in the fragmented Mongolian forest steppe. Global Change Biology 23(9):3675-3689. https://doi. org/10.1111/gcb.13750

Khishigbayar, J., M. E. Fernández-Giménez, J. P. Angerer, R. S. Reid, J. Chantsallkham, Y. Baasandorj, and D. Zumberelmaa. 2015. Mongolian rangelands at a tipping point? Biomass and cover are stable but composition shifts and richness declines after 20 years of grazing and increasing temperatures. Journal of Arid Environments 115:100-112. https://doi.org/10.1016/j.jaridenv.2015.01.007

Kis, J., S. Barta, L. Elekes, L. Engi, T. Fegyver, J. Kecskeméti, L. Lajkó, and J. Szabó 2017. Traditional herders' knowledge and worldview and their role in managing biodiversity and ecosystemservices of extensive pastures. Pages 56-70 in M. Roué and Z. Molnár, editors. Knowing our lands and resources: indigenous and local knowledge of biodiversity and ecosystem services in Europe and Central Asia. UNESCO, Paris, France.

Knapp, C. N., and M. E. Fernández-Giménez. 2009. Knowledge in practice: documenting rancher local knowledge in northwest Colorado. Rangeland Ecology and Management 62(6):500-509. https://doi.org/10.2111/08-175.1

Kristjanson, P., R. S. Reid, N. Dickson, W. C. Clark, D. Romney, R. Puskur, S. MacMillan, and D. Grace. 2009. Linking international agricultural research knowledge with action for sustainable development. Proceedings of The National Academy of Sciences 106(13):5047-5052. https://doi.org/10.1073/pnas.0807414106

Kynický, J., M. Brtnicky, D. Vavricek, and M. Uondon. 2009. Permafrost and climatic change in Mongolia. Pages 34-35 in A. Pribullová and S. Bičárová, editors. Sustainable development and bioclimate: reviewed conference proceedings. Geophysical Institute of the Slovak Academy of Sciences, Bratislava, Slovak Republic.

Lamchin, M., J. Y. Lee, W. K. Lee, E. J. Lee, M. Kim, C. H. Lim, H. A. Choi, and S. R. Kim. 2016. Assessment of land cover change and desertification using remote sensing technology in a local region of Mongolia. Advances in Space Research 57(1):64-77. https://doi.org/10.1016/j.asr.2015.10.006

Levine, J., A. Isaeva, H. Zerriffi, I. M. S. Eddy, M. Foggin, S. E. Gergel, and S. M. Hagerman. 2019. Testing for consensus on Kyrgyz rangelands: local perceptions in Naryn oblast. Ecology and Society 24(4):36. https://doi.org/10.5751/ES-11222-240436

Ligaa, U., D. Davaasuren, and N. Ninjil. 2009. Medicinal plants of Mongolia used in western and eastern medicine. Proceedings of Joint Russian-Mongolian Complex Biological Expedition, Moscow, Russia.

Lkhagvadorj, D., M. Hauck, C. Dulamsuren, and J. Tsogtbaatar. 2013a. Twenty years after decollectivization: mobile livestock husbandry and its ecological impact in the Mongolian foreststeppe. Human Ecology 41(5):725-735. https://doi.org/10.1007/ s10745-013-9599-3
Lkhagvadorj, D., M. Hauck, C. Dulamsuren, and J. Tsogtbaatar. 2013b. Pastoral nomadism in the forest-steppe of the Mongolian Altai under a changing economy and a warming climate. Journal of Arid Environments 88:82-89. https://doi.org/10.1016/j. jaridenv.2012.07.019

Mapinduzi, A. L., G. Oba, R. B. Weladji, and J. E. Colman. 2003. Use of indigenous ecological knowledge of the Maasai pastoralists for assessing rangeland biodiversity in Tanzania. African Journal of Ecology 41(4):329-336. https://doi. org/10.1111/j.1365-2028.2003.00479.x

Marin, A. 2010. Riders under storms: contributions of nomadic herders' observations to analysing climate change in Mongolia. Global Environmental Change 20(1):162-176. https://doi. org/10.1016/j.gloenvcha.2009.10.004

Moller, H., F. Berkes, P. O. Lyver, and M. Kislalioglu. 2004. Combining science and traditional ecological knowledge: monitoring populations for co-management. Ecology and Society 9(3):2. https://doi.org/10.5751/ES-00675-090302

Molnár, Z. 2012. Classification of pasture habitats by Hungarian herders in a steppe landscape (Hungary). Journal of Ethnobiology and Ethnomedicine 8:28. https://doi.org/10.1186/1746-4269-8-28

Molnár, Z. 2014. Perception and management of spatio-temporal pasture heterogeneity by Hungarian herders. Rangeland Ecology and Management 67(2):107-118. https://doi.org/10.2111/REMD-13-00082.1

Molnár, Z. 2017. "I see the grass through the mouths of my animals" - folk indicators of pasture plants used by traditional steppe herders. Journal of Ethnobiology 37:3:522-541. https://doi. org/10.2993/0278-0771-37.3.522

Molnár, Z., A. Kelemen, R. Kun, J. Máté, L. Sáfián, F. Provenza, S. Díaz, H. Barani, M. Biró, A. Máté, and C. Vadász. 2020. Knowledge co-production with traditional herders on cattle grazing behaviour for better management of species-rich grasslands. Journal of Applied Ecology 57(9):1677-1687. https:// doi.org/10.1111/1365-2664.13664

Molnár, Z., J. Kis, C. Vadász, L. Papp, I. Sándor, S. Béres, G. Sinka, and A. Varga. 2016a. Common and conflicting objectives and practices of herders and conservation managers: the need for a conservation herder. Ecosystem Health and Sustainability 2(4): e01215. https://doi.org/10.1002/ehs2.1215

Molnár, Z., D. P. Sütő, and J. Máté. 2016b. An afternoon grazing with János Máté. Documentary film. MTA Centre for Ecological Research, Vácrátót, Hungary. [online] URL: https://www. youtube.com/watch? $=\mathrm{rX}-\mathrm{KyK} \mathrm{KW} 9 \mathrm{z0}$

National Agency Meteorology and the Environmental Monitoring (NAMEM). 2019. Meteorological information. NAMEM, Ulaanbaatar, Mongolia.

National Statistics Office of Mongolia (NSO). 2019. Number of livestock. NSO, Ulaanbaatar, Mongolia. https://www.1212.mn/ tables.aspx?TBL ID=DT NSO $1001021 \mathrm{~V} 1$

Norris, J., N. Nudkhuu, T. Jal, L. Davaajii, D. Buyanjargal, N. Dvvjii, B. Ornobish, B. Erdenebat, and T. Ornobish. 2020. Synthesis of the local knowledge and ecology of Vansemberüü 
(Saussurea dorogostaiskii Palib.) for conservation, Darkhad Valley, Khuvsugul, Mongolia. Thesis. University of Vermont, Burlington, Vermont, USA. [online] URL: https://scholarworks. uvm.edu/hcoltheses/358

Oba, G. 2012. Harnessing pastoralists' indigenous knowledge for rangeland management: three African case studies. Pastoralism: Research, Policy and Practice 2:1. https://doi.org/10.1186/2041-7136-2-1

Oba, G., and L. M. Kaitira. 2006. Herder knowledge of landscape assessments in arid rangelands in northern Tanzania. Journal of Arid Environments 66(1):168-186. https://doi.org/10.1016/j. jaridenv.2005.10.020

Oba, G., and D. G. Kotile. 2001. Assessments of landscape level degradation in southern Ethiopia: pastoralists versus ecologists. Land Degradation and Development 12(5):461-475. https://doi. org/10.1002/ldr.463

Okayasu, T., M. Muto, U. Jamsran, and K. Takeuchi. 2007. Spatially heterogeneous impacts on rangeland after social system change in Mongolia. Land Degradation and Development 18 (5):555-566. https://doi.org/10.1002/1dr.796

Otgontuya, L., A. Elmarsdottir, N. Lkhagvajav, and C. Munkhbat. 2019. Influence of different grazing intensity on above-ground biomass in Mongolian rangeland. Proceedings of the Mongolian Academy of Sciences 59(3):29-38. https://doi. org/10.5564/pmas.v59i3.1244

Raymond, C. M., C. Bieling, N. Fagerholm, B. Martin-Lopez, and T. Plieninger. 2016. The farmer as a landscape steward: comparing local understandings of landscape stewardship, landscape values, and land management actions. Ambio 45:173-184. https://doi.org/10.1007/s13280-015-0694-0

Reed, M. S., and A. J. Dougill. 2002. Participatory selection process for indicators of rangeland condition in the Kalahari. Geographical Journal 168(3):224-234. https://doi. org/10.1111/1475-4959.00050

Reed, M. S., A. J. Dougill, and T. R. Baker. 2008. Participatory indicator development: what can ecologists and local communities learn from each other. Ecological Applications 18 (5):1253-1269. https://doi.org/10.1890/07-0519.1

Reed, M. S., E. D. Fraser, and A. J. Dougill. 2006. An adaptive learning process for developing and applying sustainability indicators with local communities. Ecological Economics 59 (4):406-418. https://doi.org/10.1016/j.ecolecon.2005.11.008

Rugg, G., and P. McGeorge. 1997. The sorting techniques: a tutorial paper on card sorts, picture sorts and item sorts. Expert Systems 14(2):80-93. https://doi.org/10.1111/1468-0394.00045

Sambuu J. 1987. Advice to herders how to work in livestock husbandry [Title translated from the Mongolian]. State Publishing House, Ulaanbaatar, Mongolia.

Samiya, R., and M. Mühlenberg. 2006. The nature conversation of Mongolia [Title translated from the Mongolian]. Mönkhiin Üseg Publishing, Ulaanbaatar, Mongolia

Sanchir, C., J. Batkhuu, B. Boldsaikhan, and K. Komatsu. 2003. Illustrated guide of Mongolian useful plants [Title translated from the Mongolian]. Ministry of Nature, Environment and Tourism,
Japan International Cooperation Agency, Ulaanbaatar, Mongolia.

Scharf, K., M. Fernández-Giménez, B. Batbuyan, and S. Enkhbold. 2010. Herders and hunters in a transitional economy: the challenge of wildlife and rangeland management in postsocialist Mongolia. Pages 312-339 in J. T. du Toit, R. Kock, and J. C. Deutsch, editors. Wild rangelands: conserving wildlife while maintaining livestock in semi-arid ecosystems. Wiley-Blackwell, Oxford, UK. http://dx.doi.org/10.1002/9781444317091.ch12

Seid, M. A., L. W. Yoseph, U. W. Befekadu, A. Muhammed, and T. Z. Fikre. 2016. Communication for the development of pastoralism. Revue Scientifique et Technique 35(2):639-648. http:// dx.doi.org/10.20506/rst.35.2.2545

Shen, X., and J. Tan. 2012. Ecological conservation, cultural preservation, and a bridge between: the journey of Shanshui Conservation Center in the Sanjiangyuan region, QinghaiTibetan Plateau, China. Ecology and Society 17(4):38. http://dx. doi.org/10.5751/ES-05345-170438

Solomon, A. M., and H. H. Shugart. 1993. Vegetation dynamics and global change. Springer, Boston, Massachusetts, USA. https:// doi.org/10.1007/978-1-4615-2816-6

Tengö, M., E. S. Brondizio, T. Elmqvist, P. Malmer, and M. Spierenburg. 2014. Connecting diverse knowledge systems for enhanced ecosystem governance: the multiple evidence base approach. Ambio 43(5):579-591. https://doi.org/10.1007/s13280-014-0501-3

Thurstan, R. H., S. M. Buckley, J. C. Ortiz, and J. M. Pandolfi. 2016. Setting the record straight: assessing the reliability of retrospective accounts of change. Conservation Letters 9 (2):98-105. https://doi.org/10.1111/conl.12184

Tuvshintogtokh, I., and D. Ariungerel. 2013. Degradation of Mongolian grassland vegetation under overgrazing by livestock and its recovery by protection from livestock grazing. Pages 115-130 in N. Yamamura, N. Fujita, and A. Maekawa, editors. The Mongolian ecosystem network. Springer, Tokyo, Japan. https://doi.org/10.1007/978-4-431-54052-6 10

Ujházy, N., Z. Molnár, Á. Bede-Fazekas, M. O. Szabó, and M. Biró. 2020. Do farmers and conservationists perceive landscape changes differently? Ecology and Society 25(3):12. https://doi. org/10.5751/ES-11742-250312

Ulambayar, T., M. E. Fernández-Giménez, B. Baival, and B. Batjav. 2017. Social outcomes of community-based rangeland management in Mongolian steppe ecosystems. Conservation Letters 10(3):317-327. https://doi.org/10.1111/conl.12267

Ulicsni, V., D. Babai, E. Juhász, Z. Molnár, and M. Biró. 2020. Local knowledge about a newly reintroduced, rapidly spreading species (Eurasian beaver) and perception of its impact on ecosystem services. PLoS ONE 15(5):e0233506. https://doi. org/10.1371/journal.pone.0233506

Venable, N. B. H., S. R. Fassnacht, G. Adyabadam, S. Tumenjargal, M. Fernández-Giménez, and B. Batbuyan. 2012. Does the length of station record influence the warming trend that is perceived by Mongolian herders near the Khangai Mountains. Pirineos 167:69-86. https://doi.org/10.3989/

Pirineos.2012.167004 
Ecology and Society 26(2): 21

Wang, J. A., D. Sulla-Menashe, C. E. Woodcock, O. Sonnentag, R. F. Keeling, and M. A. Friedl. 2020. Extensive land cover change across Arctic-Boreal Northwestern North America from disturbance and climate forcing. Global Change Biology 26 (2):807-822. https://doi.org/10.1111/gcb.14804 